\title{
THE RELATIONSHIP BETWEEN THE INTERNATIONAL CRIMINAL COURT AND THE U.N. SECURITY COUNCIL: PARAMETERS AND BEST PRACTICES
}

Recent developments, including calls (to date unheeded) for the U.N. Security Council to refer the situation in Syria to the International Criminal Court (ICC or the Court), the referral of the situations in Sudan and Libya to the ICC, as well as various demands that the Security Council use its deferral powers under the ICC's Rome Statute, ${ }^{1}$ highlight the importance of the relationship between the Security Council and the ICC. The Security Council (a political body) has sway over the docket of the ICC (a judicial institution) - the power to refer 'situations' over which the ICC would not otherwise have jurisdiction, and to defer investigations and prosecutions. While many states and non-governmental organizations (NGOs) have decried (and some continue to decry) the Security Council's role vis-à-

* Associate Clinical Professor of Global Affairs, N.Y.U.-S.C.P.S. Professor Trahan is Chairperson of the American Branch of the International Law Association International Criminal Court Committee, and was a member of the American Bar Association's 2010 International Criminal Court Task Force, including at the Kampala Review Conference, where she also served as an observer for the Association of the Bar of the City of New York. She has written widely on issues of international criminal justice, including two books on the case law of the ad hoc tribunals. The author would like to thank Stefan Barriga, Fernanda Millicay, Carsten Stahn, John Washburn, and two anonymous peer reviewers for their comments on this article. The author would also like to thank Erin K. Lovall for her research assistance.

${ }^{1} 1998$ Rome Statute of the International Criminal Court, 2187 UNTS 90 (Rome Statute). 
vis the ICC, ${ }^{2}$ it clearly exists under the ICC's Rome Statute. Thus, the more productive inquiry is to examine what legal parameters guide this relationship, and what additional considerations should be relevant to defining the proper interaction between these institutions.

This article, which follows on two interesting seminars that explored these issues, ${ }^{3}$ will examine the relationship between the Security Council and ICC. Part one lays out the basic parameters as to when the Security Council may make referrals, and examines whether there is any legal obligation for the Security Council to make referrals in the face of mass atrocity crimes. Part two lays out the basic parameters as to when the Security Council may defer ICC investigations and/or prosecutions. These parts also examine the referrals and deferrals made to date, and proposals for referrals and deferrals that have been made. Part three examines the language used in Security Council referral resolutions. Specifically, it considers language used in the two referral resolutions to date - Security Council Resolution 1593 (Darfur) ${ }^{4}$ and Security Council Resolution 1970 (Libya) $^{5}$ - that (a) excludes use of U.N. funds to pay for investigation and prosecution of the referred situations, (b) excludes nationals from non-ICC States Parties from ICC jurisdiction that would otherwise follow from referral of the 'situation,' and (c) only imposes cooperation obligations on the states covered by the referrals. Finally, part four explores whether some mechanism should be implemented so the Security Council, as a regular matter, conducts

\footnotetext{
${ }^{2}$ For one such critique, see E. Jiminez, 'Seeking Global Reform: The United Nations Security Council, The International Criminal Court, and Emerging Nations' (2012) 30 Macalester International 84, at 85 ('the interaction between the ICC and the Security Council undermines global justice and maintains the current delegitimized dominant order'); ibid. at 86 ('the ICC's lack of total independence from politicization as well as statutory limitations threatens its primary objective of protecting individuals from abuse of power.').

${ }^{3}$ The first meeting took place on 16 March 2012, at Chatham House in the U.K., and was sponsored by Parliamentarians for Global Action and Chatham House. The second took place on 8 November 2012, at the International Peace Institute in New York City and was sponsored by the Liechtenstein Mission to the U.N. and the International Peace Institute.

${ }^{4}$ Resolution 1593 - Reports of the Secretary-General on the Sudan, U.N. Doc. S/RES/1593 (2005) (hereinafter, 'Resolution 1593').

${ }^{5}$ Resolution 1970 - Peace and Security in Africa, U.N. Doc. S/RES/1970 (2011) (hereinafter, 'Resolution 1970').
} 
follow-up as to its referrals. The article concludes both that there are limited, but significant, legal parameters to guide interaction of the Security Council and ICC, and attempts to make a number of best practice recommendations. It also concludes that the Security Council should (a) not include in the referral resolution language that no U.N. funding accompany the referral; (b) not include language that purports to exempt nationals of non ICC-States Parties from referral of a 'situation'; (c) mandate that all U.N. Member States cooperate regarding any referral; and (d) create some kind of followup mechanism when it makes a referral in order to help ensure successful investigations and prosecutions. (A summary of this article's conclusions is located in Appendix A hereto.)

\section{LEGAL PARAMETERS AS TO WHEN THE SECURITY COUNCIL MAKES A REFERRAL}

Under the Rome Statute, the Security Council may refer a 'situation' to the ICC's Prosecutor. ${ }^{6}$ Unlike referrals by States Parties and the Prosecutor acting under his or her proprio motu power, both of which additionally require jurisdiction to otherwise exist through a state's ratification of, or accession to, the Rome Statute, Security Council referral is extremely significant because it also creates jurisdiction. ${ }^{7}$ As explained below, when the Security Council may refer a 'situation' to the ICC is governed by both the Rome Statute, and also the U.N. Charter. Whether the Security Council has any obligation to make referrals is governed by the U.N. Charter, and more recently, informed by the development of the doctrine of the 'responsibility to protect.'

\footnotetext{
${ }^{6}$ Rome Statute, supra note 1, Art. 13(b).

${ }^{7}$ If the Court is acting after State Party referral or Prosecutor referral, the provisions of Article 12(2)(a) or (b) must be met for jurisdiction to exist. Rome Statute, Article 12(2) states:

In the case of article 13, paragraph (a) [State Party referral] or (c) [Prosecutor referral], the Court may exercise its jurisdiction if one or more of the following States are Parties to this Statute or have accepted the jurisdiction of the Court in accordance with paragraph 3 :

(a) The State on the territory of which the conduct in question occurred or, if the crime was committed on board a vessel or aircraft, the State of registration of that vessel or aircraft;

(b) The State of which the person accused of the crime is a national.

Rome Statute, supra note 1, Art. 12(2). Significantly, in the case of Security Council referral under Article 13(b), there is no similar jurisdictional requirement. See Rome Statute, supra note 1, Arts. 12-13.
} 


\subsection{Requirements for Security Council Referral}

The Rome Statute's provision as to Security Council referrals is fairly brief. It states:

Article 13

Exercise of jurisdiction

The Court may exercise its jurisdiction with respect to a crime referred to in article 5 in accordance with the provisions of this Statute if:

... (b) A situation in which one or more of such crimes appears to have been committed is referred to the Prosecutor by the Security Council acting under Chapter VII of the Charter of the United Nations.... ${ }^{8}$

From the face of this provision, at least three aspects are noteworthy: (1) in terms of a threshold for action, the Security Council may act when 'one or more' ICC crimes 'appears to have been committed,' and (2) in making the referral, the Security Council must be 'acting under Chapter VII' of the U.N. Charter, but (3) even when both these conditions are met, the Court's independence is preserved in that it 'may exercise its jurisdiction,' but is not mandated to do so.

As to the threshold for action of 'one or more' ICC crimes, at first blush, that could suggest a somewhat low threshold. One murder in the proper context arguably can constitute a crime against humanity. ${ }^{9}$ Yet, the context (or chapeau) requires a 'widespread or systematic attack directed against any civilian population, with knowledge of the attack ${ }^{10}$ committed 'pursuant to or in furtherance of a State or organizational policy. ${ }^{11}$ This context necessarily requires fairly large-scale crimes to be occurring. Similarly, while Article 8 of the Rome Statute permits an isolated war crime to constitute a crime, it also suggests the Court should exercise jurisdiction 'in particular when [war crimes are] committed as part of a plan or policy or as part of a large-scale commission of such

8 Rome Statute, supra note 1, Art. 13(b) (emphasis added).

${ }^{9}$ See J. Trahan, Genocide, War Crimes and Crimes Against Humanity: A Digest of the Case Law of the International Criminal Tribunal for Rwanda (2010), at 90 (compiling cases); J. Trahan, Genocide, War Crimes and Crimes Against Humanity: A Topical Digest of the Case Law of the International Criminal Tribunal for the Former Yugoslavia (2006), at 216-217 (compiling cases).

${ }^{10}$ Rome Statute, supra note 1, Art. 7(1).

${ }^{11}$ Rome Statute, supra note 1, Art. 7(2)(a). 
crimes. ${ }^{12}$ Again, this suggests that the Court should act primarily as to large-scale war crimes. Genocide necessarily is almost always a largescale crime as it requires intent to destroy, in whole or in part, ${ }^{13}$ 'a national, ethnical, racial or religious group, as such. ${ }^{14}$ Additionally, the Rome Statute's preamble makes clear that the ICC is to prosecute 'the most serious crimes of concern to the international community as a whole. ${ }^{15}$ Thus, the threshold of 'one or more' ICC crimes is not really that low. Furthermore, one probably need not fear that the Security Council will act after only one ICC crimes appears to have been committed. If anything, practice to date shows that non-action or late-action is probably more of a concern. ${ }^{16}$ Furthermore, were the Security Council

${ }^{12}$ Rome Statute, supra note 1, Art. 8(1).

13 The 'in part' requirement has been read by at least the ICTY and ICTR to require a 'substantial part' of the group be targeted. See Trahan, supra note 9, ICTR Digest, at 27-28; Trahan, supra note 9, ICTY Digest, at 158-163 (collecting cases on the 'substantial' part requirement). Because 'incitement' is a mode of responsibility, it theoretically would be possible to incite genocide without large-scale killing occurring, see Rome Statute, supra note 1, Art. 25.3(e) (incitement as to genocide); that would, however, make a fairly weak ICC case and might not pass Article 17's gravity threshold. See Rome Statute, supra note 1, Art. 17 (gravity as a criterion of admissibility).

${ }^{14}$ Rome Statute, supra note 1, Art. 6.

${ }^{15}$ Rome Statute, supra note 1, preamble. See 1969 Vienna Convention on the Law of Treaties, 1155 U.N.T.S. 331, Art. 31.2 ('The context for the purpose of the interpretation of a treaty shall comprise in addition to the text,... its preamble and annexes....').

${ }^{16}$ See L. Moss, 'The UN Security Council and the International Criminal Court: Towards a More Principled Relationship', 2012 Friedrich Ebert Stiftung, 1, at 12 (library.fes.de/pdf-files/iez/08948.pdf) ('the problem of Security Council referrals continues to be under-inclusiveness rather than over-inclusiveness'). The Darfur referral occurred only after hundreds of thousands of fatalities. J.E. Tangaho and J.P. Hermina, 'The International Community Responds to Darfur: ICC Prosecution Renews Hope for International Justice' (2008-2009) 6 Loy. U. Chi. Int'l L. Rev. 367, at 367-368 ('Sudan's Armed Forces (SAF) and its proxy Arab Militias, the Janjaweed, have killed almost 400,000 people.'). To date, there are an estimated 100,000 fatalities in Syria, and no referral. See D. Evans and O. Holmes, 'Syria Death Toll Tops 100,000, Rebels Lose Border Town', Reuters, 26 June 2013. There were also calls (unheeded) for referral of the situation in Sri Lanka after large-scale war crimes were suspected of having been committed by both government forces and members of the Liberation Tigers of Tamil Eelam (the 'LTTE'). See Rep. of the Secretary-General's Panel of Experts on Accountability in Sri Lanka (31 March 2011), at 49-51 (www.un.org/News/dh/ infocus/Sri_Lanka/POE_Report_Full.pdf) (preliminarily concluding that war crimes were committed by both the government of Sri Lanka (shelling no fire zones, a United Nations hub, and hospitals, depriving civilians in conflict zones of humanitarian aid, and rape, torture and disappearances of suspected LTTE members) and the LTTE (taking civilians as hostages, using civilians as human shields, executing civilians who attempted to flee conflict zones, forced recruitment of children, forced labor, killing 
to act prematurely, the Prosecutor would have discretion not to proceed in any event. ${ }^{17}$ As to whether Rome Statute crimes have occurred, the Security Council has the option of relying on U.N. Secretary-General reporting to the Security Council or a Commission of Inquiry report, but is not required to do so, or wait for such reporting before it acts.

The second requirement for Security Council referral is that the Security Council act under Chapter VII of the U.N. Charter. ${ }^{18}$ This imposes an additional threshold in that Chapter VII action is only permissible under the U.N. Charter where Article 39 has been met, that is, there has been a 'threat to the peace, breach of peace or act of aggression. ${ }^{19}$ Thus, for example, commission of an isolated war crime (unless particularly large-scale), might not involve a 'threat to the peace, breach of peace or act of aggression.' It is only when Article 39 is additionally met, that the Security Council may act. (Of course, whether the Security Council is 'acting under Chapter VII' is a question for the Council initially to decide upon, ${ }^{20}$ and the Council

Footnote 16 continued civilians through suicide bombings, and using military equipment near civilians or civilian installations like hospitals)).

${ }^{17}$ See Rome Statute, supra note 1, Art. 53.1(c) (considerations for determining whether there is a reasonable basis to proceed with an investigation).

${ }^{18}$ Rome Statute, supra note 1, Art. 13(b). This requirement is found in the Rome Statute, but independently also exists in the U.N. Charter, for the Security Council to be able to act under Chapter VII.

${ }^{19}$ U.N. Charter, Art. 39. See also A. Mokhtar, 'The Fine Art of Arm-Twisting: The US, Resolution 1422 and Security Council Deferral Power Under the Rome Statute' (2003) 3 Int'l Crim. L. Rev. 295, at 311 ('UN Charter article 39... refers to a threat to the peace, breach of the peace or an act of aggression as a prerequisite for action by the [Security Council under Chapter VII].').

${ }^{20}$ R. Lavalle, 'A Vicious Storm in a Teacup: The Action by the United Nations Security Council to Narrow the Jurisdiction of the International Criminal Court' (2003) 14 Criminal Law Forum 195, at 201. See also J. Stromseth, D. Wippman, and R. Brooks, Can Might Make Right?: Building the Rule of Law After Military Interventions (2006), at 23 ('[T] Che Charter does not limit or define these terms [threat to the peace/breach of the peace/act of aggression], leaving to the Security Council the flexibility to make these determinations in concrete circumstances.'). For discussion of whether the Council's action is subject to judicial review, see n. 93. 
appears to make fairly liberal calls in this respect, sometimes recognizing that 'internal conditions within a country' 'could potentially pose a threat to peace and security. ${ }^{21}$ )

The third key parameter we see from Article 13(b) is that the Court is not required to act after Security Council referral but 'may exercise its jurisdiction, ${ }^{22}$ making clear the Court must evaluate for itself whether the proper criteria to move forward are met. Under the Rome Statute, regardless of how a situation is referred - that is, including if there is a Security Council referral - the Prosecutor undertakes a preliminary examination. ${ }^{23}$ As the OTP's Draft Policy Paper on Preliminary Examinations makes clear: "no automaticity is assumed whether the Prosecutor receives a referral from a State Party or the UN Security Council. ${ }^{24}$ Pursuant to Article 53(1)(a)-(c), the Prosecutor evaluates 'whether there is a reasonable basis to proceed with an investigation' by considering (a) jurisdiction; (b) admissibility (complementarity and gravity); and (c) the 'interests of justice. ${ }^{25}$ If these criteria are not met, the Prosecutor determines there is 'no reasonable

${ }^{21}$ See Stromseth, supra note 20, at 24, n. 11 ('The discussion regarding Article 2(7) at San Francisco in 1945 revealed considerable awareness that internal conditions within a country, including grievous violations of human rights, could potentially pose a threat to peace and security and thus give rise to enforcement action by the United Nations.'); ibid., at 32 ('UN-authorized interventions in the 1990s demonstrated the Security Council's willingness to define 'threats to the peace' more broadly and flexibly than ever before... invoking reasons for intervention that went well beyond aggression or classic cross-border threats to peace and security.').

${ }^{22}$ Rome Statute, supra note 1, Art. 13(b) (emphasis added). Article 53, by contrast, contains language that suggests more of a presumption that the Prosecutor will open an investigation upon State Party or Security Council referral. Compare Rome Statute, supra note 1, Art. 53(1) ('The Prosecutor shall, having evaluated the information made available to him or her, initiate an investigation unless he or she determines that there is no reasonable basis to proceed under this Statute.') (emphasis added).

${ }^{23}$ See ICC Office of the Prosecutor, 'Draft Policy Paper on Preliminary Examinations', 2010, at para. 2 (www.icc-cpi.int/NR/rdonlyres/9FF1EAA1-41C4-4A30-A202174B18DA923C/282515/OTP_Draftpolicypaperonpreliminaryexaminations04101.pdf) ('the Office [of the Prosecutor] conducts a preliminary examination of all situations brought to its attention based on statutory criteria and the information available'); ibid., at para. 4 ('The preliminary examination of a situation may be initiated by: (a) a decision of the Prosecutor... (b) a referral from a State Party or the Security Council; or (c) a declaration pursuant to article 12(3)....') (emphasis added) (hereinafter 'Draft OTP Policy Paper').

${ }^{24}$ Ibid., at para. 28 (emphasis added).

${ }^{25}$ See Rome Statute, supra note 1, Art. 53(1); Draft OTP Draft Policy Paper, supra note 23 , at para. 5 . 
basis to proceed. ${ }^{26}$ 'The Pre-Trial Chamber may review a decision by the Prosecutor not to proceed with an investigation. ${ }^{27}$ The Prosecutor's decision-making ability vis-à-vis whether to initiate an investigation and PreTrial Chamber review is extremely important in the event of Security Council referral to help ensure the ICC's independence from the Security Council. ${ }^{28}$ The Security Council cannot make the Prosecutor act in the event of a referral. He or she must independently conclude that there is a reasonable basis to proceed.

\subsection{Whether There is any Legal Requirement to Make a Referral}

A separate question is whether there is ever an obligation for the Security Council to make a referral, for instance, in the face of grave atrocity crimes.

First, it is significant to note that the Rome Statute imposes no such obligation on the Security Council to act, nor could it. ${ }^{29}$ While the Rome Statute governs referrals, it cannot ultimately empower or mandate the Security Council to do anything that it could not otherwise do under the

${ }^{26}$ Rome Statute, supra note 1, Art. 53(1). If the determination that there is 'no reasonable basis to proceed' is based solely on consideration of 'the interests of justice,' the Prosecutor 'shall inform the Pre-Trial Chamber.' Ibid.

${ }^{27}$ Draft OTP Policy Paper, supra note 23, at para. 98. 'Such review may be requested by the referring party, i.e. either the State Party concerned or the Security Council, or, where the Prosecutor's decision is based solely on decision the [sic] interests of justice, on the Pre-Trial Chamber's own initiative.' Ibid., at n. 67; Rome Statute, supra note 1, Art. 53(3).

${ }^{28}$ See M. El Zeidy, 'The United States Dropped the Atomic Bomb of Article 16 of the ICC Statute: Security Council Power of Deferrals and Resolution 1422' (2002) 35 Vand. J. of Transnat. L. 1503, at 1516 (even in the event of Security Council referral under Article 13(b) '[t]he prosecutor has wide discretion and can decide not to proceed in accordance with Article 53[;] [t]hus, the prosecutor and the ICC can block the Security Council's referral.'); Negotiated Relationship Agreement Between the International Criminal Court and the United Nations (2004), at pmbl. para. 4 (hereinafter, 'Negotiated Relationship Agreement') (stressing that the ICC 'is established as an independent permanent institution.'); ibid., at Art. 2 ('The United Nations recognizes the Court as an independent permanent judicial institution which... has international legal personality and such legal capacity as may be necessary for the exercise of its functions and the fulfillment of its purposes.'); Draft OTP Policy Paper, supra note 23, at para. 34 ('Article 42 of the Statute provides that the Office of the Prosecutor shall act independently of instructions from any external source').

29 'The Council is not bound by the provisions of the Rome Statute. Its authority... must... be assessed on the basis of its Chapter VII powers under the Charter.' C. Stahn, 'The Ambiguities of Security Council Resolution 1422 (2002)' (2003) 14 European J. of Int'l L., at 97; see also Mokhtar, supra note 19, at 311 ('Under Article 16 , the source of the [Security Council's] power to defer proceedings before the ICC clearly derives from Chapter VII of the UN Charter.'). 
U.N. Charter (which creates Security Council powers and obligations). Put another way, the Rome Statute is instructing the ICC Prosecutor and Judges what to do if the Security Council makes a referral. The Charter, by contrast, only grants the Security Council power vis-à-vis U.N. Member States. ${ }^{30}$ The Rome Statute could not permit or mandate the Security Council to do something vis-à-vis the ICC if the Security Council did not already have that power (or obligation) to begin with under the U.N. Charter.

The U.N. Charter also does not expressly mandate action in the face of grave crimes, although it suggests it. The Charter makes clear that one of the purposes and principles of the U.N. is "promoting and encouraging respect for human rights, ${ }^{, 31}$ and that Chapter VII action (which could include action to protect human rights) would not constitute a Charter violation as Security Council action must be consistent with the purposes of the U.N. Charter. ${ }^{32}$ Yet, even if Chapter VII is triggered by an Article 39 'threat to the peace, breach of the peace, or act of aggression' (which well may be met if large-scale atrocity crimes are occurring), ${ }^{33}$ there is not necessarily an express responsibility in the Charter for the Security Council to act. While Article 39 states that the Security Council 'shall make recommendations, or decide what measures shall be taken in accordance with Article 41 and 42 ' if there is a

${ }^{30}$ See U.N. Charter, Art. 25 ('The Members of the United Nations agree to accept and
carry out the decisions of the Security Council in accordance with the present Charter.');
N. Jain, 'A Separate Law for Peacekeepers: The Clash between the Security Council and
the International Criminal Court' (2005) 16 E.J.I.L. 239, at 253 ('an international
organization like the ICC has a separate legal personality independent of its Member
States. Under Article 25 of the U.N. Charter, mandatory [Security Council] resolutions
only create binding obligations for states, and not for international organizations con-
stituted by these states.').

${ }^{31}$ U.N. Charter, supra note 30, Art. 1.3.

${ }^{32}$ See E. Rosand, "The Security Council as "Global Legislator": Ultra Vires or Ultra Innovative?' (2004) 28 Fordham Int'l L. J., at 556. See also U.N. Charter, supra note 30, Art. 2(7) ('Nothing contained in the present Charter shall authorize the United Nations to intervene in matters which are essentially within the domestic jurisdiction of any state...; but this principle shall not prejudice the application of enforcement measures under Chapter VII.').

${ }^{33}$ See Chatham House, International Law Meeting Summary, with Parliamentarians for Global Action, 'The UN Security Council and The International Criminal Court' (16 March 2012), at 18 ('Where there are credible reports that core crimes under international law are being committed, and that those crimes appear to meet the thresholds for crimes within the jurisdiction of the ICC, this in itself could indicate to the Security Council that the situation in hand constitutes a threat to international peace and security.'). 
threat to international peace and security, ${ }^{34}$ the articles themselves use the weaker verb, that the Security Council 'may' act. Thus, in Article 40 (provisional measures), the Security Council 'may... call upon the parties concerned to comply with... provisional measures.... 35 In Article 41 (non-forceful means), the Security Council 'may decide what measures not involving the use of armed force are to be employed.... ${ }^{36}$ And, in Article 42 (forceful measures), the Security Council 'may take such action by air, sea, or land forces as may be necessary to maintain or restore international peace and security. ${ }^{37}$ While the Charter gives the Security Council 'primary responsibility' to protect international peace and security, ${ }^{38}$ and states that it has a 'duty' to maintain international peace and security, ${ }^{39}$ both of which provisions suggest the Security Council should act where there is a 'threat to the peace, breach of the peace, or act of aggression,' the more specific provisions of Articles 4042 suggest that there is no requirement that particular measures be taken, nor is there an absolute requirement that measures be taken.

Yet, today, one would not read the U.N. Charter in isolation. The doctrine of the 'responsibility to protect' has evolved subsequent to the drafting of both the U.N. Charter and the Rome Statute. Under this doctrine, the international community does have a responsibility to protect a people in peril in certain circumstances. Specifically, as formulated in a January 2009 Report on Implementing the Responsibility to Protect, the U.N. Secretary-General identified three 'pillars' to implement. ${ }^{40}$ Pillar I emphasizes that states have the primary responsibility to protect their own populations. Pillar II focuses on the responsibility of the international community to assist states in building capacity to protect their populations. Pillar III stresses the responsibility of the international community to take timely and decisive action to prevent genocide, ethnic cleansing, ${ }^{41}$ war crimes, and

\footnotetext{
${ }^{34}$ U.N. Charter, supra note 30, Art. 39 (emphasis added).

${ }^{35}$ U.N. Charter, supra note 30, Art. 40 (emphasis added).

${ }^{36}$ U.N. Charter, supra note 30, Art. 41 (emphasis added).

${ }^{37}$ U.N. Charter, supra note 30, Art. 42 (emphasis added).

${ }^{38}$ U.N. Charter, supra note 30, Art. 24 (1).

${ }^{39}$ U.N. Charter, supra note 30, Art. 24 (2).
}

${ }^{40}$ Implementing the Responsibility to Protect: Report of the Secretary General, U.N. Doc.A/63/677 (12 January 2009) (hereinafter 'Implementing the Responsibility to Protect').

41 'Ethnic cleansing' is not a crime per se under any of the tribunal statutes, but presumably refers to ethnic killing that may or may not constitute genocide. Thus, it can be a helpful term to describe such killing without making the determination of whether or not the killing rises to the level of genocide. See Implementing the Responsibility to Protect, supra 
crimes against humanity when a state is 'manifestly failing' to protect its population. ${ }^{42}$ While the 'responsibility to protect' has not formed into a fully hard-law obligation as of yet, it has been recognized by the Security Council in numerous resolutions, ${ }^{43}$ and, inter alia, the 2005 World Summit Outcome Document. ${ }^{44}$ This doctrine, thus suggests that the Security Council actually does have an emerging legal obligation (and clearly a moral obligation) to act

Footnote 41 continued

note 30 , para. 3 ('Ethnic cleansing is not a crime in its own right under international law, but acts of ethnic cleansing may constitute one of the other three crimes.').

${ }^{42}$ Implementing the Responsibility to Protect, supra note 30 . The International Commission on Intervention and State Sovereignty (ICISS) suggested that while decisions to intervene should be made by the Security Council, if the Council 'fails to discharge its responsibility to protect in conscience-shocking situations crying out for action, concerned states may not rule out other means to meet the gravity and urgency of that situation...' See 'Report of the International Commission on Intervention and State Sovereignty, The Responsibility to Protect' (2001) International Development Research Centre, at XIII, para. 3(F). Subsequent formulations, however, make clear that it is the Security Council that is to act. See, e.g., World Summit Outcome, U.N. Doc. A/60/L.1 (20 September 2005), at para. 139 ('[w] are prepared to take collective action, in a timely and decisive manner, through the Security Council....') (emphasis added).

${ }^{43}$ See U.N. Doc. S/RES/1653 (Great Lakes region); U.N. Doc. S/RES/1674 (protection of civilians); U.N. Doc. S/RES/1894 (protection of civilians); U.N. Doc. S/RES/1970 (Libya); U.N. Doc. S/RES/1973 (Libya); U.N. Doc. S/RES/1975 (Côte d'Ivoire); U.N. Doc. S/RES/1996 (South Sudan); U.N. Doc. S/RES/2014 (Yemen); U.N. Doc. S/RES/2016 (Libya); U.N. Doc. S/RES/2040 (Libya); U.N. Doc. S/RES/ 2085 (Mali). The responsibility of a state to prevent genocide was also upheld recently by the International Court of Justice in the Bosnia v. Serbia case. See Application of Convention on Prevention and Punishment of Crime of Genocide (Bosn. \& Herz. v. Serb. \& Montenegro), Judgment of 26 February 2007, [2007] I.C.J., at 43, para. 165 ('Article I [of the Genocide Convention] does impose distinct obligations over and above those imposed by other Articles of the Convention. In particular, the Contracting Parties have a direct obligation to prevent genocide.').

${ }^{44}$ World Summit Outcome, U.N. Doc. A/60/L.1 (20 September 2005), at paras. 138-139. 
in the face of large-scale atrocity crimes. ${ }^{45}$ Referral to the ICC as the sole response arguably would be a weak, and not necessarily sufficient, form of action, ${ }^{46}$ but could be useful, particularly if made early or mid-way through the commission of the crimes, in order to attempt to deter further crimes. ${ }^{47}$ Various states have also proposed that one Permanent Member of the Security Council, acting alone, should not prevent action in the face of mass atrocity through use of its veto power. ${ }^{48}$

${ }^{45}$ See A. Peters, 'The Security Council's Responsibility to Protect', 2011 International Organizations Law Review 8, at 15-16 (www.ius.unibas.ch/uploads/publics/7561/20111 011154344_4e94481005a88.pdf) ('If R2P is a legal or at least nascent legal principle, then the Security Council's duty to take sufficiently robust action in an R2P situation is not only a moral duty... but a legal one'); but see P. Asikainen and I. Österdahl, 'The Responsibility to Protect of the International Community: A Study on the Protection Duties of the United Nations and Its Member States' (2011) Uppsala University, at 64 (www.uppsalajuristernasalumnistiftelse.se/wp-content/uploads/2012/02/2011_paivi. pdf) ('As long as there are no clear legal rules imposing on the U.N. an obligation to prevent genocide, war crimes, and crimes against humanity, the Security Council's responsibility to protect can only be moral or political in nature.') (emphases in original).

${ }^{46}$ See, e.g., R. Cryer, 'Sudan, Resolution 1593, and International Criminal Justice' (2006) 19 Leiden J. of Int'l L. 195, at 222 ('[Referring] the [Darfur] matter to the ICC does mean that the Security Council is doing something, but other ways of limiting the conflict in Darfur are not being pursued as rigorously as they ought to be.... Therefore the referring of the matter to the ICC may be seen as stationing an ambulance at the bottom of a cliff, rather than erecting a fence at the top. Prevention is better than cure.').

${ }^{47}$ While one hopes to deter crimes by the use of referrals, admittedly, it is difficult to prove that deterrence in fact works. See Moss, supra note 16, at 6 ('There is much debate whether the referral of the Darfur situation has had any effect in deterring further violations of human rights and humanitarian law'); ibid., at 10 ('There is again room for debate as to whether the referral of Libya had any deterrent effect'). To the extent there is a deterrent value derived from referrals, consistency in the making of referrals could 'enhance the deterrent value.' Ibid., at 13.

${ }^{48}$ See Enhancing the Accountability, Transparency and Effectiveness of the Security Council, U.N. Doc. A/66/L.42/Rev.2 (2012), at Annex, para. 20 (tabled by Costa Rica, Jordan, Liechtenstein, Singapore and Switzerland) (recommending that the Permanent Members of the Security Council refrain 'from using a veto to block Council action aimed at preventing or ending genocide, war crimes and crimes against humanity.'); see also Citizens for Global Solutions, 'The Responsibility Not To Veto: A Way Forward' (2010) (http://globalsolutions.org/files/public/documents/ RN2V_White_Paper_CGS.pdf). 


\subsection{Security Council Referrals to Date and Proposed Referrals}

As noted above, to date, the Security Council has twice referred situations to the ICC: the situation in Darfur, Sudan by Security Council Resolution $1593^{49}$ and the situation in Libya by Security Council Resolution 1970. ${ }^{50}$

These referrals appear to pose no problem in terms of the legal parameters discussed above. Certainly the Security Council's referral of the situation in Darfur, where the fatality estimates were in the hundreds of thousands, with millions having been displaced, ${ }^{51}$ met the Rome Statute Article 13(b) threshold of 'one or more' ICC crimes appearing 'to have been committed.' It would also satisfy the Article 17(1)(d) gravity threshold that, pursuant to Article 53(1)(c), the Prosecutor is to consider in determining whether there is a reasonable basis to proceed with an investigation. ${ }^{52}$ The Libya situation might pose more questions in this respect, in that at the time of the referral the crimes were just starting. ${ }^{53}$ While that may be the best time to deter crimes, and would satisfy the Article 13(b) language that 'one or more [ICC] crimes appears to have been committed,' the referral should also consider the ICC's role to prosecute 'the most serious crimes of concern to the international community as a whole, ${ }^{54}$ and that the ICC gravity threshold must additional by satisfied for the Prosecutor to proceed with an investigation and for the case to be

\footnotetext{
49 Resolution 1593, supra note 4.

${ }^{50}$ Resolution 1970, supra note 5.

${ }^{51}$ Tangaho, supra note 16, at 367-368 ('Sudan's Armed Forces (SAF) and its proxy Arab Militias, the Janjaweed, have killed almost 400,000 people.... In addition to the murders, almost 2.5 million people [were] displaced.').

${ }^{52}$ See Rome Statute, supra note 1, Arts. 17(1)(d) and 53(1)(c). For a discussion of the appropriate criteria for evaluating gravity under the Rome Statute, see, e.g., Situation in the Democratic Republic of the Congo, ICC-01/04-169, 13 July 2006, Judgment on the Prosecutor's appeal against the decision of Pre-Trial Chamber I entitled 'Decision on the Prosecutor's Application for Warrants of Arrest, Article 58', paras. 69-82 (hereinafter 'Situation in the Democratic Republic of Congo').

${ }^{53}$ J. Liolos, 'Justice for Tyrants: International Criminal Court Warrants for Gaddafi Regime Crimes' (2012) 35 B.C. Int'l \& Comp. L. Rev. 589, at 592-594 ('By late February 2011, the popular protests in Libya became widespread and prominent; in response, the Gaddafi regime escalated its brutal crackdown on protestors.... [O]n February 26, 2011, the United Nations Security Council passed Resolution 1970 that unanimously referred the Gaddafi matter to the ICC.').

${ }^{54}$ Rome Statute, supra note 1, preamble.
} 
admissible. ${ }^{55}$ Given the crimes covered by the ICC's two warrants for crimes committed in Libya, ${ }^{56}$ these requirements appear met in the Libya scenario as well. ${ }^{57}$ In Resolutions 1593 and 1970, the Security Council also stated that it was acting under Chapter VII, ${ }^{58}$ and there does not appear reason to question that Chapter VII was properly invoked as each situation most likely did constitute a "threat to the peace, [or] breach of the peace. ${ }^{, 59}$

More significantly for current events, as explained above, the 'responsibility to protect doctrine' suggests that the Security Council may actually have an increasingly solidifying obligation to act where there are large-scale instances of genocide, war crimes and crimes against humanity. ${ }^{60}$ This suggests that the Syria referral (which at the time of the writing of this article had not occurred despite an estimated 100,000 fatalities, ${ }^{61}$ and evidence of war crimes and crimes against humanity ${ }^{62}$ ) is not only long-overdue, but referral could

${ }^{55}$ See Rome Statute, supra note 1, Art. 53(1)(c) (gravity as a criterion for proceeding with an investigation); Rome Statute, supra note 1, Art. 17(1)(d) (gravity as a criterion of admissibility).

${ }^{56}$ Saif Al-Islam Gaddafi and Abdullah Al-Senussi stand accused of murder and persecution as crimes against humanity. See TheProsecutor v. Saif Al-Islam Gaddafi and Abdullah Al-Senussi [27 June 2011], Warrant of Arrest. The case against Muammar Mohammed Abu Minyar Gaddafi (Muammar Gaddafi) was terminated subsequent to his death.

${ }^{57}$ One author argues:

[T]here was evidence of crimes against humanity and war crimes at the time the Council acted. Libyan security forces opened fire on peaceful protestors in Tripoli and in the eastern city of Benghazi, killing at least 300 people. Gadhafi himself manifested criminal intent in suppressing the protestors, calling on his supporters to 'attack them in their lairs,' and promising to fight 'to my last drop of blood.' Moss, supra note 16, at 8 .

${ }^{58}$ Resolution 1593, supra note 4, at pmbl., para. 6; Resolution 1970, supra note 5, pmbl., para. 16 .

${ }^{59}$ U.N. Charter, supra note 30, Art. 39. For discussion of whether there may be judicial review of the Security Council's invocation of Chapter VII, see n. 93.

${ }^{60}$ See Part 1.2 supra.

${ }^{61}$ D. Evans and O. Holmes, 'Syria Death Toll Tops 100,000, Rebels Lose Border Town', Reuters, 26 June 2013. The U.N. has estimated over 92,000 fatalities as of the end of April. D. Jolly, 'Death Toll in Syrian Civil War Near 93,000, U.N. Says', New York Times, 13 June 2013.

${ }^{62}$ U.N. General Assembly, Human Rights Council, Report of the Independent International Commission of Inquiry on the Syrian Arab Republic, U.N. Doc. A/HRC/22/59 (5 February 2013), paras. 1, 42-162 (detailing reported instances of war crimes and crimes against humanity committed during the Syrian crisis); see also N. Cumming-Bruce, 'U.N. Rights Officials Urge Syria War Crimes Charges', New 
constitute one possible avenue for partly satisfying 'responsibility to protect' obligations. Again, this article does not mean to suggest that an ICC referral alone is necessarily sufficient to satisfy either the 'responsibility to protect' or the Security Council's obligations to protect international peace and security; indeed, it probably is not. ${ }^{63}$

Based on the analysis above, the following conclusions may be drawn. ${ }^{64}$ In terms of the minimum number of crimes occurring for the Security Council to make a referral, Article 13(b) requires only that one or more ICC crimes 'appear[] to have been committed.' This is a fairly low threshold, but of course ICC crimes are fairly large-scale in themselves, and the purpose of the ICC is also to prosecute 'the most serious crimes of concern to the international community as a whole. ${ }^{65}$ Thus, the Security Council should probably not act absent fairly significant criminality, assessed either qualitatively and/or quantitatively. ${ }^{66}$ While some have suggested a

Footnote 62 continued

York Times, 18 February 2013, at A10 (www.nytimes.com/2013/02/19/world/ middleeast/un-rights-panel-says-violence-in-syria-is-mounting.html?_r $=0)(\mathrm{Navi}$ Pillay, the U.N. High Commissioner for Human Rights, and the U.N. Human Rights Council state that war crimes and crimes against humanity have been committed in Syria and renew requests that the Syrian crisis should be referred by the Security Council to the International Criminal Court).

${ }^{63}$ See Moss, supra note 16, at 1 (arguing that as to the situation in Darfur, 'referral was no substitute for the Council's use of other measures to restore peace and security.'); ibid., at 5 ('The Council can be faulted for not taking adequate measures to directly address the humanitarian crisis in Darfur, but not for lacking an adequate factual basis and credible process for making the referral to the ICC. The roughly 2,000 African Union (AU) soldiers then on the ground were clearly insufficient to stop the killing and displacements, and the Council imposed no sanctions or punitive measures of any kind against the Sudanese government.').

64 These conclusions are also summarized in Appendix A hereto.

${ }^{65}$ Rome Statute, supra note 1, at preamble.

${ }^{66}$ See Draft OTP Policy Paper, supra note 23, at paras. 67-70 (suggesting that gravity encompass both 'quantitative and qualitative considerations,' including the scale of the crimes, the nature of the crimes, the manner of commission, and the impact of the crimes). See also, e.g., Situation in the Democratic Republic of the Congo, at paras. 69-82 (discussing gravity). Premature action also might not satisfy the requirement that the Security Council act under Chapter VII in making the referral. 
Security Council referral should not occur absent a full commission of inquiry, ${ }^{67}$ this author would not necessarily advocate a rigid rule. The Security Council also may not act unless Chapter VII is additionally, satisfied, that is, there is an actual 'threat to the peace, breach of the peace, or act of aggression.' The Security Council should also not wait too late in the day to act, or any deterrent value of the referral will be lost. In terms of whether the Security Council has any obligation to make a referral in the face of grave crimes, the relevant legal analysis should, in addition to the U.N. Charter, also be guided by the 'responsibility to protect' doctrine, which suggests that the Security Council does indeed have an emerging legal obligation (and certainly a moral obligation) to act in the face of large-scale atrocity crimes, with referral constituting one possible step. The Security Council should also be concerned about showing consistency in making referrals using as objective criteria as possible ${ }^{68}$ - for the sake of its own

${ }^{67}$ See Moss, supra note 16, at 9 ('[i]n hindsight, it might have been better to allow a full process of inquiry to establish the facts justifying referral' of the Libya situation); see also ibid., at 12 ('The UN High Commissioner for Human Rights has suggested possible triggers for a referral might include a resolution of the Human Rights Council or advice from the ICC Prosecutor, in addition to an international commission of inquiry report, and possibly a role for OHCHR.').

${ }^{68}$ See Moss, supra note 16, at 1 ('In using its power of referrals, the Council should apply criteria and processes that are as objective and consistent as possible' to minimize danger to the 'independence and legitimacy of the ICC,' so that Council decisions are not seen as 'politically motivated'); see also Chatham House, supra note 33, at 4 ('It was suggested that the elaboration of criteria would provide civil society and likeminded states with a set of principles that they could apply in order to put pressure on the Council to refer situations....'). 
institutional credibility, for the sake of the institutional credibility of the ICC, ${ }^{69}$ and for the Security Council to show itself a responsible actor in the face of large-scale atrocity crimes that threaten international peace and security.

\section{LEGAL PARAMETERS FOR THE SECURITY COUNCIL'S USE OF ITS DEFERRAL POWERS}

Under Article 16 of the Rome Statute, the Security Council may also 'defer' an ICC 'investigation or prosecution. ${ }^{, 70}$ To date, the Security Council has used Article 16 in only one instance - Resolution 1422, addressing peacekeeping operations, ${ }^{71}$ and its renewal, in resolution $1487 .^{72}$ There have additionally been requests for the Security

${ }^{69}$ As the U.N. Secretary-General has acknowledged:

[T] here remain serious challenges in pursuing accountability. Some situations which, by any objective analysis, would have warranted some form of action by the Security Council, have faced serious obstacles or languished entirely. This has eroded the Council's credibility. There is a need to address this problem, and to bring some consistency to the effort.

U.N. Secretary-General, Honouring Geneva Conventions, Secretary-General Says Debate 'No Longer Between Peace And Justice But Between Peace And What Kind Of Justice', U.N. Doc. SG/SM/12494, L/T/4417, HR/5002 (26 September 2009) (http://unispal.un.org/UNISPAL.NSF/0/857F5A937A9F5F808525763F005C2A9C). Summarizing a roundtable discussion at the International Peace Institute, it was also concluded that:

The UN Security Council should apply consistent standards when referring cases to the ICC, even if this may be difficult to achieve in practice. The Security Council is a political body, and decisions on situations to be referred to the ICC will continue to be influenced by its political nature. But consistency remains an important goal, because perceptions of the legitimacy and integrity of the ICC depend on it.

T. Papenfuss, International Peace Institute Meeting Brief, 'The Relationship Between the ICC and the Security Council: Challenges and Opportunities,' at 1, para. 1.

${ }^{70}$ Rome Statute, supra note 1 , art. 16.

${ }^{71}$ United Nations Peacekeeping - Resolution 1422, U.N. Doc. S/RES/1422 (2002) (hereinafter, 'Resolution 1422'). Resolution 1422 was adopted by unanimous vote.

${ }^{72}$ United Nations Peacekeeping - Resolution 1487, U.N. Doc. S/RES/1487 (2003) (hereinafter, 'Resolution 1487'). Resolution 1487 was adopted by a vote of 12 in favour with three abstentions - France, German and Syria. Lavalle, supra note 20, at 219, n. 46. 
Council to utilize Article 16: (1) the request by the African Union (AU) and others that the ICC $\operatorname{defer}^{73}$ the case against Sudanese President Omar Hassan Ahmad Al Bashir against whom the ICC has issued two arrest warrants $;{ }^{74}$ and (2) Kenya's request, supported by the African Union, ${ }^{75}$ that the ICC defer the ICC's investigations and

${ }^{73}$ After the ICC applied for a warrant for Sudanese President Omar Hassan Ahmad Al Bashir on 14 July 2008, the African Union's Peace and Security Council (AU PSC) requested that the U.N. Security Council defer the process initiated by the ICC in accordance with Rome Statute Article 16 'taking into account the need not to put in jeopardy the ongoing peace efforts, as well as the fact that, in the current circumstances, a prosecution may not be in the interest of the victims and justice.' The AU PSC reiterated its deferral request at its 22 September 2008 meeting. The AU Assembly endorsed the decision of the AU PSC at its 142nd meeting and expressed its deep concern regarding the warrant. The AU and various African States Parties to the Rome Statute continued to request a deferral after the first warrant for Bashir was issued on 4 March 2009. S. Weldehaimanot, 'Arresting AlBashir: The African Union's Opposition and the Legalities' (2011) 19 Afr. J. Int'l \& Comp. L. 208, at 214-216. See also Moss, supra note 16, at 7 ('The AU Peace \& Security Council and the Organization of the Islamic Conference (OIC) both requested that the Security Council suspend prosecution under Article 16 of the Rome Statute, with support from the Arab League.').

As to the AU's argument, 'an African Union communiqué criticiz[ed] the warrant request. The communiqué asserted that:

approval by the Pre-Trial Chamber of the [warrant] application by the ICC Prosecutor could seriously undermine the ongoing efforts aimed at facilitating the early resolution of the conflict in Darfur and... the Sudan as a whole and, as a result, may lead to... far-reaching consequences for the country and the region. Consequently, the AU requested that the Security Council invoke Article 16 to "defer the process initiated by the ICC," referring to the Prosecutor's request that the PreTrial Chamber issue an arrest warrant.' War Crimes Research Office, Washington College of Law, 'The Relationship Between The International Criminal Court and the United Nations' (August 2009), at 22 (www.wcl.american.edu/warcrimes/icc/ documents/WCRO_Report_on_ICC_and_UN_August2009.pdf) (footnotes omitted).

${ }^{74}$ The Prosecutor v. Omar Hassan Ahmad Al Bashir, First Warrant of Arrest, ICC02/05-01/09, 4 March 2009 (hereinafter, 'Bashir First Arrest Warrant'); The Prosecutor v. Omar Hassan Ahmad Al Bashir, Second Warrant of Arrest, ICC-02/05-01/09, 12 July 2010 (hereinafter, 'Bashir Second Arrest Warrant').

${ }^{75}$ Kenya made efforts to convince other countries that the U.N. Security Council should defer the Kenyan cases. The African Union supported Kenya's efforts. The Kenyan government made a formal deferral request to the U.N. Security Council on 8 February 2011. The Kenyan government stated that because "some of the individuals mentioned by the ICC Prosecutor are among the front runner presidential candidates and the civil servants mentioned are in office and charged with responsibilities for peace and security," the ICC process poses "a real and present danger to the exercise of government and the management of peace and security in the 
prosecutions as to post-election crimes committed in Kenya. ${ }^{76}$ Analysis of the legal parameters for utilizing Article 16 suggests that there are serious questions whether Resolutions 1422 and 1487 were proper uses of Article 16, and there are substantial questions whether the proposed deferrals would constitute, or would have constituted, proper uses of Article 16.

\subsection{Requirements for Security Council Deferral}

Rome Statute Article 16 states: 'No investigation or prosecution may be commenced or proceeded with under this Statute for a period of 12 months after the Security Council, in a resolution adopted under Chapter VII of the Charter of the United Nations, has requested the Court to that effect; that request may be renewed by the Council under the same conditions. 77

From the face of this provision, at least two aspects are noteworthy: (1) in making the deferral, the Security Council must be acting under Chapter VII of the U.N. Charter; and (2) when it makes a deferral no ICC 'investigation or prosecution' may be commenced or proceeded with. Because a deferral lasts only 12 months, renewal would be made under the same terms. ${ }^{78}$

The requirement that the resolution be 'adopted under Chapter VII of the Charter' means that the Security Council may not act without the situation first triggering the threshold language of U.N. Charter Article 39 , that there be a 'threat to the peace, breach of the peace, or act of aggression. ${ }^{, 79}$ Any renewal after 12 months would have to satisfy the

Footnote 75 continued

country." T. Hansen, "Transitional Justice in Kenya - An Assessment of the Accountability Process in Light of Domestic Politics and Security Concerns' (20112012) 42 Cal. W. Int'l L.J. 1, at 12-13 (citation omitted).

${ }^{76}$ The ICC is slated to go to trial on the cases The Prosecutor v. Uhuru Muigai Kenyatta, ICC-01/09-02/11, and The Prosecutor v. William Samoei Ruto and Joshua Arap Sang, ICC-01/09-01/11.

${ }^{77}$ Rome Statute, supra note 1, Art. 16 (emphasis added).

78 'Article 16 does not limit the number of times a deferral request, may be renewed, which could be read literally to permit infinite renewals.' El Zeidy, supra note 28, at 1515.

${ }^{79}$ U.N. Charter, supra note 30, Art. 39. See also Mokhtar, supra note 19, at 311 ('Article $39 \ldots$ refers to a threat to the peace, breach of the peace or an act of aggression as a prerequisite for action by the [Security Council].'). 
same threshold. ${ }^{80}$ One question that arises is: if the Security Council purports to act under Chapter VII (it adopts a resolution that states that it is), does the ICC separately inquire whether the Security Council properly acted under Chapter VII, or does it simply check that the resolution says that it did so act? Another question might be: who provides the 'threat to the peace,' and can it be the state or person asking for, or benefiting from, the deferral? In other words, does there need to be some external 'threat to the peace, breach of the peace, or act of aggression' to which the Security Council is responding, or can, for instance, the President of Sudan create a 'threat to the peace' and thereby merit deferral of his own prosecution? Neither the Rome Statute nor the U.N. Charter provides much specific guidance here. ${ }^{81}$

As to the requirement that no 'investigation or prosecution' be commenced or proceeded with if the deferral is made, one question that arises is whether the deferral must be of a specific 'investigation or prosecution,' as Human Rights Watch ${ }^{82}$ and

${ }^{80}$ Rome Statute, supra note 1, Art. 16. To the extent that Resolution 1422 suggests it will be automatically renewed, see Resolution 1422, supra note 71, para. 2, that arguably runs roughshod over Article 16's requirement that a deferral lasts only 12 months. See El Zeidy, supra note 28, at 1525 (suggesting the potentially indefinite duration of Resolution 1422 was problematic); Mokhtar, supra note 19, at 329 (intent to automatically renew Resolution 1422 violates the 'letter and the spirit of Article 16').

${ }^{81}$ These questions are addressed in the next section when considering the validity of Resolution 1422. Views expressed by a number of states in voting on Resolution 1422 suggest strong disagreement with the resolution, and, particularly, skepticism as to whether Chapter VII was properly triggered. See Amnesty International, 'International Criminal Court: The unlawful attempt by the Security Council to give US citizens permanent impunity from international justice' (May 2003), at 7 (www. amnesty.org/fr/library/asset/IOR40/006/2003/en/b585efec-d6f8-11dd-b0cc-1f086001 $3475 /$ ior 400062003 en.pdf) (there was 'overwhelming opposition of states from all regions and all legal systems [to Resolution 1422].'); ibid., at 17-23, 26-33 (chronicling extensive opposition by many states to Resolution 1422). See also El Zeidy, supra note 28, at 1519-1523 (most of the Security Council viewed Resolution 1422 as dangerous and negatively impacting on international law, as well [impacting] on credibility of the current and future Council decisions') (chronicling views of various countries).

${ }^{82}$ Human Rights Watch argues:

The phrase, "no investigation or prosecution may be commenced or proceeded with," presupposes the existence of a particular "investigation" or "prosecution" that relates to a specific incident or the potential culpability of an individual regarding specific conduct. Article 15 of the Rome Statute spells this out. The PreTrial Chamber must authorize the commencement of a specific "investigation." All prosecutor inquiries up to this point are not "investigations," but only 
others ${ }^{83}$ have argued, or can be made pre-emptively to cover a category of potential investigations or prosecutions not yet commenced at the time of the deferral. Again, the face of Article 16 does not seem to offer significant guidance, although, as explained below, other Rome Statute provisions may be relevant. ${ }^{84}$

\subsection{Security Council Deferrals to Date}

As noted above, there has been only one use, or purported use, of Article 16 - Resolution 1422, renewed by Resolution 1487. Resolution 1422 states that it grants immunity from ICC prosecution to 'current or former officials or personnel from a contributing State not a Party to the Rome Statute' related to U.N.-authorized peacekeeping operations. ${ }^{85}$ The key operative text of Resolution 1422 is as follows:

The Security Council,...

Acting under Chapter VII of the Charter of the United Nations,

1. Requests, consistent with the provisions of Article 16 of the Rome Statute, that the ICC, if a case arises involving current or former officials or personnel from a contributing State not a Party to the Rome Statute over acts or omissions relating to a United Nations established or authorized operation, shall for a twelve-month period starting 1 July 2002 not commence or proceed with investigation or prosecution of any such case, unless the Security Council decides otherwise.... ${ }^{86}$

Footnote 82 continued

"preliminary examinations" - see Article 15(6). Only after Pre-Trial Chamber authorization of an "investigation" is the Security Council entitled to request a deferral under Article 16.

Human Rights Watch, 'The ICC and the Security Council: Resolution 1422, Legal and Policy Analysis' (www.hrw.org/legacy/campaigns/icc/docs/1422legal.htm).

${ }^{83}$ See, e.g., Cryer, supra note 46, at 210 (Article 16 covers 'deferral of particular investigations or prosecutions' and not whole categories of individuals).

${ }^{84}$ For background on the drafting of Article 16, see M. Bergsmo and J. Pejić, in O. Triffterer (ed.), Commentary on the Rome Statute of the International Criminal Court: Observers' Notes, Article by Article (2008), at 595-604; El Zeidy, supra note 28, at 1509-1512; Mokhtar, supra note 19, at 302-306.

${ }^{85}$ Resolution 1422, supra note 71, para. 1. Resolution 1422 passed less than two weeks after the July 2002 activation of the Rome Statute. Lavalle, supra note 20, at 206

${ }^{86}$ Resolution 1422, supra note 71, para. 1. El Zeidy explains that the US insisted on Resolution 1422 because it did not obtain all its negotiating points during the ICC's Rome negotiations. See El Zeidy, supra note 28, at 1507-1508. See also D. Scheffer, All the Missing Souls: A Personal History of the War Crimes Tribunals (2012), chapters 7-8 (chronicling US negotiating points up to and during the Rome Conference). 
The first question that might arise is whether there was a legitimate "threat to the peace, breach of peace, or act of aggression' that necessitated this resolution - in other words, whether this was proper Chapter VII action. Some background is in order here. Prior to passage of Resolution 1422, the U.S., which had long-standing concerns about the ICC having jurisdiction over its armed forces, threatened to veto the U.N. Peacekeeping Mission in Bosnia-Herzegovina (UNMIBH), unless US soldiers were granted immunity from ICC prosecution. ${ }^{87}$ The crisis was 'averted by adoption of Security Council Resolution 1422. ${ }^{88}$ A question therefore exists whether there was in fact a 'threat to the peace' or 'breach of the peace' that legitimated Resolution $1422 ?^{89}$ At least several scholars and others have argued that there was not. ${ }^{90}$ Was

87 'If the Council would not accept the proposal [to grant immunity to US soldiers in Bosnia and Herzegovina from ICC jurisdiction for one year], then the United States threatened to use its veto power to stop the renewal of the period of their mission in Bosnia-Herzegovina, which was to expire on July 15, 2002.' El Zeidy, supra note 28, at 1505. See also Amnesty International, supra note 81, at 3 (the only such threat to the peace 'reportedly cited during the closed sessions of the Security Council was the threat by the USA to veto the extension of UNMIBH and other UN peace-keeping operations.'); Mokhtar, supra note 19, at 313 ('The US clearly stated that, should the SC refuse immunity for its soldiers, it would veto the renewal of the UNMIBH.'). For additional discussion of the US position on the ICC, see Part 3.2 infra.

${ }^{88}$ Lavalle, supra note 20, at 195-196. See also Stahn, supra note 29, at 85 ('This compromise [Resolution 1422] dissolved the threat of a US veto against future United Nations peacekeeping operations.... Furthermore, it represents a significant retreat from the initial US demand for permanent immunity of US military personnel within the framework of peacekeeping operations.').

89 'The Security Council never made this determination [that Article 39 was triggered] in resolution 1422.' Human Rights Watch, supra note 82.

${ }^{90}$ See Stahn, supra note 29, at 104 ('The Council stretched its Chapter VII powers to its utmost limits when treating the issue of the immunity of peacekeepers as a matter of international peace and security under Article 39 of the Charter.'); Lavalle, supra note 20, at 209 (Resolution 1422 is 'unconstitutional' because the resolution contained no determination of a 'threat to the peace, breach of the peace, or act of aggression' and there would have been no factual basis for such a determination); Amnesty International, supra note 81, at 1 ('the Security Council did not even attempt to determine that there was a threat to or breach of international peace and security. Indeed, it could not have done so since there simply was no such threat.'); Amnesty International, supra note 81, at 19 (remarks of Switzerland 'one cannot really see that the fact that the Court is able to exercise its jurisdiction over the members of a peace-keeping operation would be a threat to peace.'). 
a threat to future peacekeeping operations a 'threat to the peace'?' Or was the threat to the UN's future ability to respond to demands for peacekeeping, and not a real 'threat to the peace'?' Thus, there does seem reason to question whether Chapter VII was properly invoked (and therefore whether the first criterion for Article 16 deferral was met). Yet, should the ICC sit in judgment of the Security Council and evaluate such issues? ${ }^{93}$ Or does Article

${ }^{91}$ See, e.g., El Zeidy, supra note 28, at 1524 ('The Council could probably witness that impeding the contribution of peacekeepers by any means, including judicial interference, might harm the Council's efforts to maintain international peace and security. This conclusion might be acceptable, particularly in light of the overwhelming international support to assist Bosnia and Herzegovina.'). On balance, El Zeidy, however, finds Resolution 1422 infirm for a variety of reasons. See El Zeidy, supra note 28, at 1540, 1544 (concluding that Resolution 1422 is ultra vires: it conflicts with international law principles engrained in the UN Charter, the Law of Treaties, and certain customary and peremptory norms.').

${ }^{92}$ See Lavalle, supra note 20, at 201, n. 210 ('impairing the ability of the United Nations to respond to threats to the peace is something quite different from creating such a threat.'); Stahn, supra note 29, at 87 ('[T] he threat to the peace seems to be based less on the existence of a specific conflict situation than on the potential inability of the United Nations to address future threats without US military personnel. Such an assumption raises serious concerns, because it ultimately implies that the non-contribution of troops to United Nations peacekeeping operations is in itself a threat to the peace.'); Amnesty International, supra note 81, at 63 ("“To assert that a matter may have a distant repercussion on the maintenance of peace is not enough to [justify Security Council action]."') (quoting Legal Consequences for States of the Continued Presence of South Africa in Namibia (South West Africa) notwithstanding Security Council Resolution 276, Advisory Opinion, [1971] ICJ Rep. 293, at 340 (separate opinion, Gross. J.).)

93 See, e.g., Lavalle, supra note 20, at 201 (whether the Council is 'acting under Chapter VII' 'is a question that... only the Council can decide upon.'); compare Prosecutor v. Tadic, Appeals Chamber's Decision on the Defence Motion for Interlocutory Appeal on Jurisdiction, Case No. IT-94-1-AR72, 2 October 1995, para. 30 (hereinafter, 'Tadic') (finding the situation in the former Yugoslavia constituted a "threat to the peace"); Amnesty International, supra note 81, at 62 ('In the Tadic case, the Appeals Chamber of the ICTY squarely rejected the decision of the Trial Chamber that the Security Council's determination under Article 39 was a nonjusticiable political question that could not be subject to judicial review.'); Amnesty International, supra note 81, at 65 ('Most commentators agree that Security Council determinations under Article 39, although open to a wide degree of discretion, are subject to the legal limits that there be a bona fide threat to international peace and security.') (citing various sources).

Amnesty International suggests that it is the role of the ICC to decide whether Article 16 has been properly triggered; thereby, it would not be directly judging whether the Security Council has properly acted under Chapter VII:

the ICC must be 'convinced that a decision has been taken that would impose a requirement under Article 16 of the Rome Statute - not a requirement under the UN Charter - to defer the investigation or prosecution. The International Criminal 
16 merely require the ICC to check that the resolution invokes Chapter $\mathrm{VII}^{94}$ and if such language exists, the inquiry is fully met? ${ }^{95}$ Furthermore, as a policy matter, as noted above, one might question whether the person or state creating the threat should be the beneficiary of a deferral that would cover, inter alia, its nationals? For the Security Council to grant a deferral based on a threat to international peace and security by a state whose national would benefit from the deferral could subject the Security Council

Footnote 93 continued

Court - not the Security Council - has the sole responsibility for interpreting this exceptional statutory provision authorizing the Security Council to request a temporary deferral of an investigation or a prosecution of the worst crimes in the world.' Amnesty International, supra note 81, at 36-37; see also ibid., at 39 ('it is possible for the International Criminal Court to assess the compatibility with the Rome Statute of a request by the Security Council... based solely on the nature of the request without having to decide the more sensitive question whether the Security Council exceeded its powers under the UN Charter and other international law.'). Compare El Zeidy, supra note 28, at 1515 ('Professor Schabas stated, "the [ICC] could assess whether or not the Council was validly acting pursuant to Chapter VII."'), citing W. Schabas, An Introduction to the International Criminal Court (2001), at 66 .

${ }^{94}$ Resolution 1422 states that the Security Council is acting under Chapter VII, as does Resolution 1487. See Resolution 1422, supra note 71; Resolution 1487, supra note 72 .

${ }^{95}$ For a contrary view, see Amnesty International, supra note 81, at 40 ('Of course, it goes without saying that it is not enough for the Security Council simply to say that a request was adopted under Chapter VII; such a labelling exercise cannot be decisive.'). 
to "permanent blackmail. ${ }^{96}$ One might also argue that a threat by a permanent member of the Security Council would be particularly problematic. $^{97}$

A second question that arises is whether Article 16 only permits deferral of a specific 'investigation' or 'prosecution,' or whether the deferral may be effective even before there is any such 'investigation or prosecution.' In other words, Resolution 1422 did not defer any particular 'investigation or prosecution' regarding peacekeepers or officials from non-States Parties, but acted pre-emptively so that no such investigation or prosecution could arise. The text of Rome Statute Article 16 is not entirely clear in this respect, but various

${ }^{96}$ A recent Chatham House report explained:

The Security Council may find that if it is successfully lobbied by a state under investigation to make a deferral on the basis that an investigation presents a threat to international peace and security, then it will be faced with permanent blackmail by a recalcitrant regime in order to induce the Council to renew the deferral every twelve months. States could implicitly threaten the Council with recommencing violence should it decide not to renew a deferral. Not only would this enable regimes to continually delay the administration of justice, but it would also run counter to the Security Council's primary responsibility for the maintenance of international peace and security.

Chatham House, supra note 33, at 16. See also K. Roth, 'Workshop: The International Criminal Court Five Years On: Process or Stagnation?' (2008) 6 J. Int'l Crim. Just. 763, at 767 ('allowing individuals indicted by the ICC to threaten a refusal to enter into peace negotiations or to escalate an ongoing conflict if the Security Council does not defer the Prosecution's proceedings would only encourage other groups to engage in the same practice'); War Crimes Research Office, supra note 73, at 32 ('it would appear inconsistent with the purpose of Article 16 to request a suspension of ICC proceedings in a case where a government is attempting to coerce a deferral (or a complete amnesty from prosecution) in exchange for disarming or even engaging in peace negotiations.').

${ }^{97}$ Mokhtar, supra note 19, at 313 ('A threat to the peace does not already exist in such a situation [when Resolution 1422 was adopted]; rather, the US is threatening to create one.'); see also ibid. (arguing that a U.S. threat is a misuse of the 'right granted to it by virtue of Article 27 of the UN Charter' and breach of 'the obligation to act in good faith [as] enshrined in Article 2(2).'); ibid., at 344 (questioning whether a 'Permanent Members of the Security Council may use the veto power to threaten international peace and security'). 
authors have concluded that ' $[\mathrm{t}]$ he drafting history of Article 16 indicates that it was intended to apply to concrete cases. ${ }^{98}$

A third question one might ask as to the validity of Resolutions 1422 and $1487^{99}$ is whether it is consistent with the Rome Statute to render a particular category of persons effectively immune from prosecution. The fact that Article 27 provides that there shall be no exemption from ICC responsibility for 'official capacity as a Head of State or Government, a member of a Government or parliament, an elected representative or a government official ${ }^{100}$ suggests that at least those categories of persons may not be rendered immune based on their capacity. Yet,

${ }^{98}$ Lavalle, supra note 20 , at 211. "“[T]he negotiating history makes clear that recourse to article 16 is on a case-by-case basis only, where a particular situation... warrants a twelve-month delay." Lavalle, supra note 20, at 211. See also Stahn, supra note 29, at 89 (Article 16 'was negotiated to enable the Council to delay the exercise of jurisdiction by the ICC in situations in which the resolution of a specific conflict warrants a deferral of prosecution.'); ibid. at 90 ('Article 16 was certainly not meant to provide a basis for the immunity of a whole group of actors in advance and irrespective of any concrete risk of indictment or prosecution.'); Moss, supra note 16, at 4 ('These resolutions [1422 and 1487] were legally dubious, as there was no investigation or prosecution underway to be "deferred" under Article 16. As David Scheffer, the Clinton Administration's lead negotiator in the Rome negotiations has written, Article 16 "was never intended to serve as a generic impunity carve-out for vast categories of participants in unknown future military operations and atrocity situations."'); Amnesty International, supra note 81, at 5 (similar). Compare El Zeidy, supra note 28, at 1512 ('The ICC Statute does not define what it considers an "investigation and prosecution." The statute indicates, however, that an "investigation" involves an action that may be taken with respect to both a situation or an individual, while a "prosecution" involves actions taken with respect only to a specific person.').

${ }^{99}$ Resolution 1487 was not renewed when it expired after 12 months. See D. Forsythe, 'The UN Security Council and Response to Atrocities: International Criminal Law and the P-5' (2012) 34 Human Rights Quarterly 841, at 851 ('[P]risoner abuse at the US-run Abu Ghraib prison in Iraq in 2003, publicized in 2004 ended... US demands [for further renewal of Resolutions 1422 and 1487].').

${ }^{100}$ Rome Statute, supra note 1, Art. 27 (emphasis added). It continues: 'Immunities or special procedural rules which may attach to the official capacity of a person, whether under national or international law, shall not bar the Court from exercising its jurisdiction over such a person.' Rome Statute, supra note 1, Art. 27(2). 
Resolution 1422 does in fact purport to grant immunity, inter alia, to 'current or former officials' in respect to peacekeeping operations. ${ }^{101}$ Thus, even assuming the Security Council acted permissibly in passing Resolutions 1422 and 1487 - as it has extremely broad powers to act under Chapter VII of the Charter ${ }^{102}-$ a different question is whether the Prosecutor and Judges (whose actions are governed by the Rome Statute $)^{103}$ would recognize the validity of a Security Council resolution if they view it as inconsistent with Article $27 .^{104}$

A fourth question as to the validity of Resolutions 1422 and 1487 is whether they conflict with the jurisdiction regime of Article 12(2) of the Rome Statute by 'establish[ing] a distinction between individuals from state parties and third states that is not provided for under the jurisdictional regime of the ICC. ${ }^{105}$ Under this reading, the

${ }^{101}$ Resolution 1422, supra note 71, para. 1.

102 See, e.g., U.N. Charter, supra note 20, Art. 41 (providing an open-ended list of permissible Security Council action when non-forcefully responding under Chapter VII). See also Tadic, supra note 93, para. 39 ('Article 39 leaves the choice of means and their evaluation to the Security Council, which enjoys wide discretionary powers in [acting under Chapter VII].'); Stromseth, supra note 20, at 23 ('[T]he Security Council's authority to take action is broad and includes a wide spectrum of potential responses, from diplomatic measures to economic sanctions to the use of force.').

${ }^{103}$ Article 1 of the Rome Statute states: 'The jurisdiction and functioning of the Court shall be governed by the provisions of this Statute.' Rome Statute, supra note 1, Art. 1. See also Cryer, supra note 46, at 213, n. 96 ('The Court, not a member of the UN... is obliged by Art. 21 of the Rome Statute to apply "in the first place, the Statute, Elements of Crimes and its Rules of Procedure and Evidence."'); ibid., at 206 ('the ICC, as an independent judicial body, must act according to its Statute.').

${ }^{104}$ Human Rights Watch provides one explanation of why peacekeeper immunity is inconsistent with the Rome Statute:

Article 27 of the Rome Statue expressly prohibits making distinctions on the basis of official capacity. It is a crucial provision that encompasses the fundamental object and purpose of the treaty to ensure that no person is above the law. This includes peacekeepers, as well as politicians and heads of state. Without strict adherence to this principle, the door to impunity will remain open. In contrast, Resolution 1422 allows an entire class of individuals to escape judgment of the ICC, opening the door to impunity if national courts of non-states parties fail to carry out good faith investigations and prosecutions. It is a clear violation of Article 27 of the Statute.

Human Rights Watch, supra note 82. See also Mokhtar, supra note 19, at 324 (finding Resolution 1422 contrary to Article 27 of the Rome Statute).

${ }^{105}$ See Stahn, supra note 29, at 93 (arguing that Resolution 1422 conflicts with Rome Statute Article 12(2)). Kevin Jon Heller asks whether the Security Council can tinker with the Rome Statute in such fundamental ways: 


\section{resolutions represent an unauthorized amendment to the Rome Statute. ${ }^{106}$}

One possibility is that when a treaty (the Rome Statute) - be it Article 12(2) (the jurisdictional regime), Article 16 (deferrals), Article

\section{Footnote 105 continued}

Could [the Security Council] pass a resolution deferring an ongoing investigation or prosecution in perpetuity, even though Art. 16 limits the Security Council's deferral power to one-year increments? Could it refer a situation to the Court that took place in the 1970s - some of the worst excesses of the Dirty War, perhaps even though the terms of Art. 126 limit the Court's temporal jurisdiction to actions that took place after 1 July 2002? Could it deem an aggression prosecution necessary to protect international peace and security, even though the aggression amendments are not yet operative?

K.J. Heller, 'Can the Security Council Implicitly Amend the Rome Statute?', Opinio Juris (http://opiniojuris.org/2013/01/15/can-the-security-council-implicitly-amend-therome-statute/).

${ }^{106}$ One author argues as follows:

The cumulative effect of these resolutions [1422 and 1487] is to carve out an exception from the Rome Statute for members of non-party states in UN peacekeeping operations. This exclusion would amount to an amendment to the Rome Statute and violate the law of treaties under which treaties may be amended only in the manner provided for in their constitutive instruments.

Jain, supra note 30, at 250. See also El Zeidy, supra note 28, at 1504 ('One dominant theory posits that the adoption of Resolution 1422 delineates the Council's intent to augment its powers by amending the International Criminal Court Treaty.'); ibid., at 1523 ('The competence of the Council to amend treaties without states' consent and to act as a judicial body in order to interpret a provision set out in a treaty is uncertain.'); Mokhtar, supra note 19, at 328 ('To adopt a resolution that turns a provision of a treaty on its head and gives rise to an effect that was never intended by the drafters is, in effect, to amend the negotiated terms of that treaty.'); Mokhtar, supra note 19, at 331 (arguing that an unauthorized amendment is also contrary to Article 18 of the Vienna Convention on the Law of Treaties).

It has also been argued that Resolution 1422 conflicts with: (i) Rome Statute Article 86, Amnesty International, supra note 81, at 7 and 77; (ii) the object and purpose of the Rome Statute, Mokhtar, supra note 19, at 332; (iii) the purposes and principles of the U.N. Charter, Mokhtar, supra note 19, at 318, 343; (iv) the Charter's preamble, Mokhtar, supra note 19, at 319; (v) U.N. Charter Article 1(1), Mokhtar, supra note 19, at 320; (vi) U.N. Charter Article 2(1) (principle of sovereign equality), Mokhtar, supra note 19, at 322; (vii) jus cogens norms, El Zeidy, supra note 28, at 1535; Mokhtar, supra note 19, at 338, 343; and (viii) customary law and Geneva Convention and Genocide Convention obligations, Mokhtar, supra note 19, at 339-341, made relevant through Rome Statute Article 21.1(b). 
27 (no immunities), or other articles - conflicts with action mandated by the Security Council under Chapter VII of the U.N. Charter, then it is the Security Council's obligations that prevail. Indeed, this appears to be suggested by Article 103 of the U.N. Charter, which provides: 'In the event of a conflict between the obligations of the Members of the United Nations under the present Charter and their obligations under any other international agreement, their obligations under the present Charter shall prevail. ${ }^{107}$ So, in other words, under this reading, the obligations of U.N. Member States to adhere to a Chapter VII resolution would trump the obligations of ICC States Parties to adhere to the Rome Statute. ${ }^{108}$ In fact, it appears that the Security Council has altered treaty provisions through Chapter VII action, for example, in requiring Libya to extradite two suspects pertaining to the Lockerbie bombing, thereby overriding the 1971 Montreal Convention for the Suppression of Unlawful Acts against the Safety of Civil Aviation. ${ }^{109}$ There are at least two possible responses to this. One is that a proper Chapter VII action could have this effect - but, as argued above, it is entirely questionable whether Resolutions 1422 and 1487 were proper Chapter VII actions. ${ }^{110} \mathrm{~A}$ second response is that Article 103 is not precisely on point (nor the Libya example), because the Charter imposes obligations on U.N.

${ }^{107}$ U.N. Charter, supra note 30, Art. 103.

${ }^{108}$ See Lavalle, supra note 20, at 204 ('[T] he Council may require action by States that is inconsistent with a treaty to which they are parties'); ibid., at 205 (concluding that 'the Council may require States parties to the Rome Statute, the ICC as a whole or any of its organs, to conduct themselves in ways inconsistent with any provision of the Rome Statute or with the Rome Statue as a whole.').

109 See Lavalle, supra note 20, at 203 \& n. 17-18 (the Council, pursuant to, inter alia, Article 103 of the Charter, may cause states 'to act in ways... inconsistent with their obligations and rights under [other] treaties to which they are parties'), citing Resolution 748, depriving Libya of its rights under the 1971 Montreal Convention for the Suppression of Unlawful Acts against the Safety of Civil Aviation with respect to the extradition of two fugitives pertaining to the Lockerbie bombing. Lavalle also gives the example that the Council could, under Chapter VII, 'temporarily suspend the innocent passage of foreign ships through territorial sea' in contravention of the United Nations Convention on the Law of the Sea. Ibid., at 204.

${ }^{110}$ See Lavalle, supra note 20, at 212 (Resolution 1422 is not an amendment to the Rome Statute because it is 'unconstitutional' so should 'have no effect.'); El Zeidy, supra note 28, at 1533 ('Article 103 should not be invoked because conditions precedent or the obligations which were supposed to arise from the Resolution and required to activate the Article do not exist.'); Mokhtar, supra note 19, at 326 (because the requirements of the U.N. Charter 'have not been satisfied' invocation of Article 103 would not be justified). 
Member States (and the Lockerbie surrender obligations did pertain to a state, Libya), but the Rome Statute obligations at issue provide directives to the Prosecutor and Judges, not to states. ${ }^{111}$ Thus, 'the Court enjoys its own, independent legal personality under Article 4 of the Rome Statute and is therefore not directly bound by resolutions of the Council addressed to United Nations Member States. ${ }^{112}$ Put another way, the Rome Statute instructs the Prosecutor and Judges what to do if the Security Council makes a deferral, which they would construe presumably in light of all provision of the Rome Statute, including Articles 12(2), 16, and 27. ${ }^{113}$

Clearly, it is best to avoid a conflict between the Security Council and the Court, ${ }^{114}$ and, in any event, both Resolutions 1422 and 1487 have now expired, ${ }^{115}$ so the Judges and Prosecutor will not face this dilemma. Yet, these issues could still resurface if similar jurisdictional exceptions are utilized as to peacekeeping or peace enforcement deployments and troops or officials from non-ICC States Parties commit Rome Statute crimes. (As discussed below, similar legal issues exist as to language in Security Council referral Resolutions 1593 and

${ }^{111}$ See Stahn, supra note 29, at 102 ('[T] he Charter [is] an instrument which creates legal duties for its members, but does not impose obligations on other international organizations or entities themselves.'); Mokhtar, supra note 19, at 326 ('Article 103 is speaking to the UN Members, thus it does not have the same effect on the ICC.').

${ }^{112}$ Stahn, supra note 29, at 88 (footnotes omitted).

${ }^{113}$ An alternative interpretation of Resolutions 1422 and 1487 is that they provide directives to U.N. Member States 'not to send anyone to the ICC if [the person] is a [national of a non-state party].' Response to Kevin Jon Heller, supra note 105. According to this reading:

Under Article 25 of the UN Charter all decision of the Security Council are obligations upon states to "accept and carry out." At the same time, Article 98 of the [Court's] Statute allows states to refrain from cooperating with the Court if they have a competing international obligation, in this case, this U.N. Security Council resolution.

Ibid.

114 'UNSC resolutions 1422 and 1487 had no practical effect, and a referral that didn't include nationals of non-state parties is unlikely to have an effect, unless the OTP wants to imperil the institution by doing something like pursuing Russian officials for aiding and abetting.' Response to Kevin Jon Heller, supra note 105.

${ }^{115}$ For one discussion of the validity of the non-States Parties jurisdictional carve out in U.N. Security Council Resolution 1497, see S. Zappala, 'Are Some Peacekeepers Better than Others? UN Security Council Resolution 1497 (2003) and the ICC,' 1 J. of Int'l Criminal Justice (2003) 671, at 675 (concluding that because there was no legitimate threat to peace, Resolution 1497 was ultra vires). 
1970, both of which purport to exempt from ICC jurisdiction certain nationals of non ICC-States Parties from referral of the situation. $)^{116}$

\subsection{Requests for Security Council Deferrals}

As to the requests to date that Article 16 be utilized, as noted above, the AU has requested that the warrant against Sudanese President Bashir be deferred, and Kenya has requested that the cases covering crimes committed in Kenya be deferred. ${ }^{117}$ Article 16 deferrals in these instances would clearly be deferring existing 'investigations or prosecutions' - if we read that requirement into Article 16 - because there are two arrests warrants outstanding against President $\mathrm{Ba}-$ shir, ${ }^{118}$ and three Kenyan nationals slated to proceed to trial. ${ }^{119}$

The more significant question is whether either deferral was, or would be, required to address a 'threat to the peace, breach of the peace or act of aggression' - the required trigger language for Chapter VII action. ${ }^{120}$ There is no evidence that the warrants against President Bashir cause or caused a legitimate 'threat to the peace, breach of the peace or act of aggression.' While President Bashir did expel humanitarian relief efforts subsequent to the issuance of his first warrant, ${ }^{121}$ to have permitted the deferral arguably would have allowed him to be rewarded by his own 'threat to the peace.' (He later permitted resumption of humanitarian relief, ${ }^{122}$ so to the extent there was any 'threat to the peace' it appears to have terminated.) Again, as noted above, it seems poor policy to let the person or state who would benefit from deferral be the person or state creating the threat to the peace. While arguments were made that the Bashir warrants would

116 See part 3.2 infra.

117 See notes 73 \& 75 supra.

118 Bashir First Arrest Warrant, supra note 74; Bashir Second Arrest Warrant, supra note 74.

119 Prosecutor v. Uhuru Muigai Kenyatta, ICC-01/09-02/11, and Prosecutor v. William Samoei Ruto and Joshua Arap Sang, ICC-01/09-01/11.

${ }^{120}$ U.N. Charter, supra note 30, Art. 39.

121 'Sudan's Bashir Says 10 Aid Agencies Expelled', Reuters, 5 Mar. 2009 (www.reuters.com/article/2009/03/05/idUSL5720994) (on 5 March 2009, one day after the ICC issued its first warrant for President Bashir, Reuters reported that Bashir expelled ten foreign aid agencies.).

122 'Sudan "Allows Agencies Back", BBC, 12 June 2009 (http://news.bbc.co.uk/ 2/hi/africa/8096214.stm) (starting in June, 2009, Sudan began to allow aid agencies back into Sudan provided that the agencies registered under slightly altered names and $\log$ os). 
also undermine ongoing peace negotiations, that also does not appear to have been the case. ${ }^{123}$ Similarly, as to the Kenya situation, whereas there have been periodic fears of violence and some actual violence subsequent to the commission of the crimes subject to the ICC's warrants, the situation is not caused by the ICC's prosecutions, but exist independently. ${ }^{124}$ Thus, deferral also does not appear to have been or be warranted in this situation.

${ }^{123}$ One policy paper explains:

[O]n 14 July 2008, the Prosecutor asked Pre-Trial Chamber I to issue an arrest warrant for President al-Bashir on allegations of war crimes, crimes against humanity, and genocide. In response, the government of Sudan, supported by Russia, China, Libya, the African Union (AU), and the League of Arab States, argued that the Security Council should exercise its authority under Article 16 to request the suspension of the proceedings in Darfur, claiming that the issuance of an arrest warrant against al-Bashir would undermine ongoing efforts to find a peaceful resolution to the conflict in Darfur.

War Crimes Research Office, supra note 73, at 3. See also ibid., at 5 (concluding it is difficult to make the case that the Security Council should request the deferral of proceedings against President al-Bashir' because '[d]eferral of the proceedings... could not... be seen as a means to maintain peace.'); Chatham House, supra note 33, at 16 ('there are no serious peace talks taking place that could be blocked, and the arrest warrant did not hamper the negotiation of the peace agreement regarding South Sudan....').

Another possible argument is that the Security Council should not use Article 16 to defer when it is responsible for the Article 13 referral in the first place, see War Crimes Research Office, supra note 73, at 16, but ultimately concluding that 'Article 16 permits the Security Council to seek to defer its own referrals.' Ibid., at 27.

${ }^{124}$ Calls for Kenya deferrals also do not seem linked to any 'threat to the peace, or breach of the peace,' but rather a change of heart by the government (once it became clear the ICC was interested in prosecuting government figures) as to proceeding at the ICC, rather than through a domestic process. See Moss, supra note 16, at 11 ('The Council was entirely correct [in not granting a deferral related to the Kenya cases], as deferral must be made under Chapter VII of the UN Charter and therefore requires a finding that ICC investigation would pose a threat to international peace and security'); Chatham House, supra note 33, at 15 ('[I]t was observed that the Kenyan objections to the ICC's investigations into the post-election violence only came to light once the Prosecutor revealed the individuals under investigation.'); 'Meeting Examines Kenya's Peaceful Elections', African Press International, 24 May 2013 (http://africanpress.me/2013/05/24/meeting-examines-kenyas-peaceful-elections/) (discusses relative peace during elections and ICC's deterrent effect).

To the extent Kenya made a 'complementarity' argument - that its national courts should be utilized in lieu of the ICC - that did not present a threat to international peace and security warranting deferral. See Chatham House, supra note 33, at 16 ('In the context of the Kenyan indictments, the justifications to invoke Article 16, for instance the validity of the principle of complementarity, are disconnected from the legal basis for a deferral, namely the existence of a threat to international peace and security.'). 
In summary, as to Article 16, one can conclude that deferral is only proper when (1) there is an actual 'threat to the peace, breach of peace or act of aggression'; and (2) possibly, when there is an actual 'investigation or prosecution' that needs to be suspended. Additionally, it may be problematic to have deferrals that are inconsistent with Rome Statute Article 27 (non-immunity provisions). Measured against these criteria alone, ${ }^{125}$ questions arise as to whether Resolutions 1422 and 1487 were proper uses of Article 16. Deferrals of the Bashir warrants and Kenya cases also do not appear to be proper uses of Article 16, as there has been no 'threat to the peace, breach of peace or act of aggression' that has necessitated the deferrals. Sound policy would also suggest that the person or state advocating deferral should not be the person or state creating the 'threat to the peace' that purportedly justifies deferral.

\section{THE TEXT OF THE REFERRAL RESOLUTION}

A further question is what language a Security Council referral resolution should contain (or not contain). Two very criticized aspects of the two referral resolutions to date, Security Council Resolutions 1593 and 1970, have been language whereby (1) the Security Council disallowed, or at least purported to disallow, allocation of U.N. funds to the ICC to pursue investigation and prosecution of the referred situations, and (2) the Security Council excepted from jurisdiction certain nationals of non-ICC States Parties from referral of the situation. Both provisions raise significant pragmatic and legal issues. Additionally, both resolutions imposed cooperation obligations only upon the state at issue (Sudan and Libya). A better practice would be for future referral resolutions to impose cooperation obligations on all U.N. Member States.

${ }^{125}$ Additional arguments can be made questioning the validity of Resolutions 1422 and 1487. See n. 106 supra. 


\subsection{Whether the Security Council may Disallow the General Assembly from Allocating U.N. Funds for an ICC Referral}

Given the budget constraints the ICC has been facing, with an everexpanding number of investigations and cases, and demands for more investigations and prosecutions, it has been a matter of serious concern to ICC officials and Rome Statute States Parties ${ }^{126}$ that the two referral resolutions to date contain language that none of the expenses incurred in connection with the referral shall be borne by the U.N. ${ }^{127}$ Clearly, the Rome Statute does not require that funding accompany referrals (nor could the Rome Statute mandate that the Security Council or General Assembly allocate funding, as both those entities derive their powers from the U.N. Charter). Yet, pragmatically, if the Security Council, for example, makes a number of consecutive referrals without funding accompanying them, the Court could be in a serious predicament of having insufficient funding to investigate and/or prosecute the referred situations. ${ }^{128}$ This potential problem has led some to suggest that the Prosecutor should decline to initiate an investigation on a referred situation for which she does not have sufficient funding, by invoking Article 53.1(c) that it would 'not serve the interests of justice' to proceed if unable to do so properly due to lack of sufficient funding. ${ }^{129}$ Security Council member states, particularly, but not limited to Rome Statute States Parties, should, in the interests of ensuring the success of referrals, exclude this lan-

${ }^{126}$ See, e.g., Chatham House, supra note 33, at 7 ('If the Court is to fulfil its mandate, it is imperative that it has the appropriate financial cooperation and support of the relevant institutions; whether it be the payment of dues by states parties to the Rome Statute, or whether it be from the United Nations when the Security Council makes a referral.').

${ }^{127}$ Resolution 1593, supra note 4, para. 7; Resolution 1970, supra note 5, para. 8.

${ }^{128}$ See, e.g., Papenfuss, supra note 69, at 2, para. 3 (arguing that lack of funding 'could undermine the viability of the court'). The ICC could then be in the difficult position of having to take resources away from cases already in progress in order to proceed with another unfunded Security Council referral. Author e-mails with John Washburn.

${ }^{129}$ See K.J. Heller, 'A Few Thoughts on a Syria Referral', Opinio Juris (http://opiniojuris.org/2013/01/14/a-few-thoughts-on-a-syria-referral/); see also Rome Statute, supra note 1, Art. 53.1(c) ('In deciding whether to initiate an investigation, the Prosecutor shall consider whether... [t]aking into account the gravity of the crime and the interests of victims, there are nonetheless substantial reasons to believe that an investigation would not serve the interests of justice'). 
guage, leaving it to the General Assembly to consider the matter of funding. ${ }^{130}$

Additionally, a serious legal question exists whether the Security Council actually has the power not to have U.N. funds allocated to the referral, when budget decisions, under the U.N. Charter, are made by the General Assembly. ${ }^{131}$ Specifically, as noted above, the Security Council has power to act under Chapter VII, ${ }^{132}$ and in making referrals, it necessarily must act under Chapter VII. ${ }^{133}$ At the same time, the U.N. Charter provides that ' $[\mathrm{t}$ ] he General Assembly shall consider and approve the budget of the Organization. ${ }^{134}$ Certainly, there is some potential for a conflict between the Security Council's Chapter VII powers and the General Assembly's funding powers, with no clear resolution as to which body prevails. ${ }^{135}$ Even if the Security Council provides that no funding should accompany a referral to the ICC (as it has), it is unclear that the General Assembly would need to abide by that language, since these are independent bodies, and Security Council resolutions are binding on U.N. Member States, ${ }^{136}$ but not necessarily the General Assembly as a

${ }^{130}$ A more benign interpretation of the language in Resolutions 1593 and 1970 related to U.N. funding is that both resolutions merely 'recognize[]' that no U.N. funds were, at the time of the referrals, allocated to pay for them, but that the resolutions do not attempt to preclude the General Assembly from allocating funds. This interpretation would certainly be in line with the U.N. Charter. Author e-mails with Stephan Barriga.

${ }^{131}$ U.N. Charter, supra note 30, Art. 17.1. See also Cryer, supra note 46, at 206 ('By virtue of Article 17 of the UN Charter, exclusive authority over budgetary matters is reserved to the General Assembly.') (footnote omitted).

${ }^{132}$ See U.N. Charter, supra note 30, Chapter VII.

${ }^{133}$ See Rome Statute, supra note 1, Art. 13(b).

${ }^{134}$ U.N. Charter, supra note 1, Art. 17.1.

${ }^{135}$ Article 12.1 of the Charter states 'While the Security Council is exercising in respect of any dispute or situation the functions assigned to it in the present Charter, the General Assembly shall not make any recommendation with regard to that dispute or situation unless the Security Council so requests.' Yet, this may refer to substantive matters of international peace and security, and not necessarily funding. Article 103 of the UN Charter comes into play when there is a conflict between obligations imposed under the Charter and obligations imposed under another treaty, but not to a potential conflict within the Charter. See U.N. Charter, supra note 1, Art. 103.

${ }^{136}$ See U.N. Charter, supra note 30, Art. 25 ('The Members of the United Nations agree to accept and carry out the decisions of the Security Council in accordance with the present Charter.'). 
whole. ${ }^{137}$ The Rome Statute itself also suggests that the General Assembly is the body that would allocate U.N. funds to pay for Security Council referrals, ${ }^{138}$ as does the Relationship Agreement between the ICC and the U.N. ${ }^{139}$

No doubt, this kind of dispute should be avoided. This author is not recommending that the General Assembly necessarily allocate funding to the two referred situations when the Security Council has attempted to preclude that. ${ }^{140}$ Yet, the fact that it is not so clear that

${ }^{137}$ See, e.g., Moss, supra note 16, at 6 (the Security Council should have remained silent as to budget matters when it made its referrals because "Article 17 of the UN Charter grants the General Assembly (GA) exclusive authority over budgetary matters.'); Cryer, supra note 46, at 206-207 ('It is questionable whether the Security Council can pre-empt the General Assembly's competence in this way....'); ibid., at 207 ('It may legitimately be inferred... that the Security Council is not able to pre-empt the judgment of the General Assembly on budgetary measures....'); ibid. ('to allow the Security Council to dictate questions of funding would represent a considerable transfer of authority to the Security Council outside any Charter authority[.]').

${ }^{138}$ Article 115 states: 'The expenses of the Court and the Assembly of States Parties... shall be provided by the following sources:... (b) Funds, provided by the United Nations, subject to the approval of the General Assembly, in particular in relation to the expenses incurred due to referrals by the Security Council.' Rome Statute, supra note 1, Art. 115 (emphasis added). See also M. Halff and D. Tolbert, in O. Triffterer (ed.), Commentary on the Rome Statute of the International Criminal Court: Observers' Notes, Article by Article (2008), at 1712 ('The phrase "subject to the approval of the General Assembly" [in article 115 of the Rome Statute] appears to... confirm the obvious: budgetary provisions for the payment of expenses by the UN require the General Assembly's approval. The budgetary primacy of the General Assembly is anchored in the Charter of the United Nations...'); Cryer, supra note 46, at 206 ('the UN should not be able to redirect the costs of the activities of its organs (in this case the Security Council).').

${ }^{139}$ Article 13, para. 1, states:

1. The United Nations and the Court agree that the conditions under which any funds may be provided to the Court by a decision of the General Assembly of the United Nations pursuant to article 115 of the Statute shall be subject to separate arrangements. The Registrar shall inform the Assembly of the making of such arrangements.

Negotiated Relationship Agreement, supra note 28, Art. 13, para. 1 (emphasis added). Unhelpfully, the Negotiated Relationship Agreement appears to contemplate the forming of 'separate arrangements' before the General Assembly may provide funding to the ICC. Author e-mails with C. Stahn.

140 The U.S., under the Bush Administration, made a rather 'provocative statement' warning against attempting to provide U.N. funding for the Darfur referral: "we want to be clear that any effort to retrench on that principle [no expenses of referral being borne by the UN] by this or other organizations to which we contribute could result in our withholding funding or taking other action in response."” 
the Security Council may actually mandate the General Assembly not allocate funding is good reason the Security Council should avoid similar language in future referrals.

The U.S. most likely has had, and likely continues to have, particular concern about the prospect of U.N. funds being utilized to pay for ICC investigations and prosecutions. U.S. dues comprised $22 \%$ of the U.N. budget for 2013, ${ }^{141}$ and the U.S. has a current legislative ban on funding the ICC. ${ }^{142}$ Thus, the argument is sometimes made that the U.S. may not permit U.N. funds to go to the ICC as doing so would violate U.S. law. Yet, one possible reading of U.S. law is that it prohibits direct U.S. funding to the ICC, so that there would be no problem with U.N. dues being utilized. Another possibility is that the U.S. should work towards repealing legislation that prevents U.S. funding in order to be able to support the ICC monetarily on a caseby-case basis, a step that would certainly increase U.S. engagement with the ICC and benefit the ICC. ${ }^{143}$ If the Security Council supports a referral, and the U.S. is either voting for it or abstaining (which is necessarily the case for the vote to pass), then all Security Council states (including the U.S.) should bear some responsibility for

Footnote 140 continued

Cryer, supra note 46, at 207 (quoting US acting permanent representative, Anne Patterson, U.N. Doc. S/PV.5158, at 4).

${ }^{141}$ U.N. Secretariat, Assessment of Member States' Contributions to the United Nations Regular Budget for the Year 2013 and of New Member States' Advances to the Working Capital Fund for the Biennium 2010-2011 and Contributions to the United Nations Regular Budget for 2011 and 2012, U.N. Doc. ST/ADM/SER.B/866 (24 December 2012), at 6 (www.un.org/ga/search/view_doc.asp?symbol=ST/ADM/ SER.B/866).

${ }^{142}$ The Admiral James W. Nance and Meg Donovan Foreign Relations Authorization Act, expressly prohibits the use of funds to the ICC, stating that '[n]one of the funds authorized to be appropriated by this or any other Act may be obligated for use by, or for support of, the International Criminal Court unless the United States has become a party to the Court pursuant to a treaty made under Article II, section 2, clause 2 of the Constitution of the United States on or after the date of enactment of this Act.' Foreign Relations Authorization Act (H.R. 3427), Public Law No. 106-113 (29 November 1999), at \$§ 705-706.

${ }^{143}$ The American Branch of the International Law Association International Criminal Court Committee, of which this author is chairperson, has recommended this by letter dated 24 July 2013 to U.S. Ambassador-at-Large Stephen J. Rapp, Office of Global Criminal Justice, and William K. Lietzau, Deputy Assistant Secretary of Defense (Detainee Policy). See http://ila-americanbranch.org/reports/ 20130724_ICC_Letter.pdf. 
ensuring the success of the referral. It therefore seems both wise practice to have the General Assembly decide on funding, and poor practice to continue to utilize language to the contrary, which may not be an effective legal constraint on General Assembly action in any event. Another (less preferable) option would be to create a voluntary fund for each referral, and seek voluntary contributions, as has been the Secretary-General's approach to funding the Special Court for Sierra Leone, Special Tribunal for Lebanon, and the Extraordinary Chambers in the Courts of Cambodia. ${ }^{144}$

\subsection{Whether the Nationals of Non-States Parties may be Excluded from the Referral}

An even more contentious issue concerns the exclusions of nationals from non-ICC States Parties from ICC jurisdiction when situations are referred. As mentioned above, language to this effect has been included in both of the past two referral resolutions. Thus, for example, Security Council Resolution 1970, inter alia:

Decides that nationals, current or former officials or personnel from a State outside the Libyan Arab Jamahiriya which is not a party to the Rome Statute of the International Criminal Court shall be subject to the exclusive jurisdiction of that State for all alleged acts or omissions arising out of or related to operations in the Libyan Arab Jamahiriya established or authorized by the Council, unless such exclusive jurisdiction has been expressly waived by the State[.] ${ }^{145}$

Security Council Resolution 1593 contains similar language. ${ }^{146}$

The U.S. was the key proponent of including such language. ${ }^{147}$ While evaluating all issues implicated as to whether the nationals of

${ }^{144}$ This Author finds the voluntary funding option less preferable because it can hamstring work if funding is not forthcoming, and can require Prosecutors to expend energy fundraising rather than on their primary duties.

145 Resolution 1970, supra note 5, para. 6.

146 Resolution 1593, supra note 4, para. 6. See Cryer, supra note 46, at 208 (discussing the Statute of the Special Court for Sierra Leone and Resolution 1497 (Liberia) as precedent for the jurisdictional carve-out for nationals of non-ICC States Parties).

147 According to Robert Cryer:

As a quid pro quo for its abstention [on the Darfur referral], the United States insisted on three things, the first being that no funding would be forthcoming from the UN for the costs of the investigations in Darfur... The second demand made by the United States was that the resolution make reference to the (controversial) bilateral immunity agreements that it ha[d] made with a number of countries.... [The third was] the inclusion of operative paragraph 6 [the carve-out of jurisdiction as to peacekeepers who are nationals of non ICC-States Parties].

Cryer, supra note 46, at 204-205. 
non-ICC States Parties should be excluded from referrals is beyond the scope of this article, suffice it to say that many other states, particularly ICC States Parties, view these exemptions as a form of exceptionalism. ${ }^{148}$ This is particularly so because three of the Permanent Members of the Security Council (the U.S., China, and Russia) are non-ICC States Parties. These three states therefore have the power to vote for or against referrals and deferrals (including veto power), but then may ensure that their nationals are exempt not only from direct referral, but even exempt from referrals of other situations, in the event one of their nationals were implicated, for example, in crimes committed in Darfur or Libya.

As to the U.S., this exclusion can be seen as following on the heels of a virulent anti-ICC campaign that occurred during the first term of the Bush II Administration - part of which included insistence on Resolutions 1422 and 1487. ${ }^{149}$ While the second four years of the Bush II Administration did not continue with this same hostility to the ICC (as can be seen from the fact that the U.S. did not veto the Darfur referral, but abstained from voting), ${ }^{150}$ U.S. support for the exclusion reflects continuing wariness of the ICC within certain areas of the U.S. government. While one might look forward to the day when the U.S. is willing to deploy its armed forces or support referrals without seeking such exclusions from ICC jurisdiction, that

${ }^{148}$ Cryer, supra note 46, at 217 (carve-outs of jurisdiction for non-States Parties create the perception of "double standards" and "two track justice") (quoting comments of the permanent representative of Algeria as to Resolution 1593). See also Papenfuss, supra note 69, at 1, para. 2 ('The wider negative implications for the ICC's credibility, impartiality, and independence suggest that future use of exemptions should be avoided.').

149 See Part 2.2 supra.

${ }^{150}$ See Cryer, supra note 46, at 221 ('abstention [on the Darfur referral was] a move away from the scathing anti-ICC rhetoric that ha[d] characterized the contributions of some members of the US government to the debate'), citing remarks of J.R. Bolton. There were many reasons for the US abstention, including exhaustion of efforts by the US to find acceptable alternatives. For an explanation of why the US abstained on the Darfur vote, see Cryer, supra note 46, at 199-205. 
day is not at hand. ${ }^{151}$ The U.S. has sometimes argued that it has military exposure that other countries do not bear, ${ }^{152}$ and in some ways this is correct. It is not the same thing to evaluate such questions from the perspective of countries such as Liechtenstein or Samoa. ${ }^{153}$ While this author does not support the U.S. in always seeking to exclude itself from such exposure, it is not necessarily an irrational position. (Seeking such exclusions as to peacekeeping and peace enforcement deployments in fact appears mandated by current U.S. law.) ${ }^{154}$ While a country can always avoid ICC jurisdiction by prosecuting crimes genuinely through its own domestic system, it is the ICC that will judge under the standards of Rome Statute Article 17 the genuineness of national court prosecutions - that is, if national courts are 'willing' and 'able' to prosecute. ${ }^{155}$ If this standard is not

${ }^{151}$ This author does not share the assessment that it is so unlikely as to be practically impossible that personnel, military or a fortiori civilians, belonging to United Nations peace operations could commit crimes failing within the jurisdiction of the ICC.' Lavalle, supra note 20, at 216.

${ }^{152}$ See, e.g., W. Lietzau, 'The United States and the International Criminal Court: International Criminal Law After Rome: Concerns from a U.S. Military Perspective' (2001) 64 Law \& Contemp. Probs. 119, at 125-129 ('The U.S. military has been much criticized for its stance on... the ICC Statute, but what the critics sometimes fail to recognize are the unique and vital national security responsibilities of the U.S. armed forces and the consequences of their front-line role in carrying out the nation's national security strategy.'). Lietzau represented the Department of Defense as part of the U.S. negotiating team at both the Rome Conference and the Kampala Review Conference.

${ }^{153}$ The situations of the U.K. and France are, however, probably more comparable; both countries are periodically involved in foreign military interventions, yet both are Rome Statute States Parties. Author e-mails with Stephan Barriga.

154 The so-called American Servicemembers' Protection act has a provision that states:

the President should use the voice and vote of the United States in the United Nations Security Council to ensure that each resolution of the Security Council authorizing any peacekeeping operation under chapter VI of the charter of the United Nations or peace enforcement operation under chapter VII of the charter of the United Nations permanently exempts, at a minimum, members of the Armed Forces of the United States participating in such operation from criminal prosecution or other assertion of jurisdiction by the International Criminal Court for actions undertaken by such personnel in connection with the operation.

American Servicemembers' Protection Act of 2002 (H.R. 4775), Public Law No. 107-206 (as amended 17 October 2006 and 28 January 2008), §105(a).

${ }^{155}$ See Rome Statute, supra note 1, Art. 17 (defining 'unwilling' and 'unable'). The U.S. generally is not 'unable' to hold trials that would satisfy Article 17's standards, 
met and jurisdiction exists, then the state's nationals could, and arguably should, face ICC exposure. Of course, one hopes to reach a point where all countries are willing and able to prosecute genocide, war crimes, and crimes against humanity if committed by their nationals, or be willing to have the ICC do so. ${ }^{156}$ While the U.S. under the Obama Administration has a policy of positive 'engagement' with the ICC, ${ }^{157}$ its position regarding exclusions from jurisdiction for the nationals of non-ICC States Parties apparently has not changed, since such an exclusion was included in the Libya referral (negotiated during the Obama Administration). ${ }^{158}$

A different question entirely is whether such exclusion language is valid as a legal matter. It is fairly clear that the U.N. Security Council

\section{Footnote 155 continued}

although there might be certain lacunae in U.S. law that could make the exercise of complementarity difficult, for instance, the absence of any crimes against humanity legislation. More saliently, however, issues as to 'unwillingness' could arise.

${ }^{156}$ As former U.S. War Crimes Ambassador David Scheffer and his co-author have eloquently articulated: 'The benefits of support of the ICC far outweigh the presumed costs, particularly in American credibility and leadership in its foreign policy and its commitment to the rule of law globally. This is especially true for the U.S. Armed Forces, which have far more to gain from participating in bringing leading perpetrators of atrocity crimes to justice than from continued U.S. opposition to the ICC and absence from its vital work.' D. Scheffer and J. Hutson, 'Strategy for U.S. Engagement with the International Criminal Court' (2008) A Century Foundation Report, at 21.

157 'U.S. Engagement With The International Criminal Court and The Outcome of the Recently Concluded Review Conference', remarks of Harold Hongju Koh, Legal Advisor U.S. Department of State, and Stephen J. Rapp, Ambassador-atLarge for War Crimes Issues (Washington, DC, 15 June 2010) at http://geneva. usmission.gov/2010/06/15/u-s-engagement-with-the-icc/ [viewed 2/9/13].

${ }^{158}$ An exclusion from ICC jurisdiction for non-ICC States Parties was also included in the crime of aggression amendment adopted at the Kampala Review Conference, negotiations that also occurred during the Obama Administration. See Rome Statute, supra note 1, Art. 15bis, para. 5 ('In respect of a State that is not a party to this Statute, the Court shall not exercise its jurisdiction over the crime of aggression when committed by that State's nationals or on its territory.').

In terms of US motivations, one author argues:

[T]he most important members of the Security Council usually approach the subjects of criminal law not primarily or uniquely with a long term and strategic view of what should transpire for the common good in a lawful world order, but rather with strong consideration of how they can adequately manage to protect their immediate subjective national interests given various pressures and power realities.

Forsythe, supra note 99 , at 842. 
has very broad powers when acting under Chapter VII, ${ }^{159}$ so it most likely has power to make this exclusion. ${ }^{160}$ A more salient inquiry is whether the Judges and Prosecutor (who are governed by the Rome Statute) ${ }^{161}$ have to respect the validity of such an exclusion, when Rome Statute Article 13(b) states that the Security Council shall refer a 'situation."162 Does this then permit the Security Council to refer less than a full situation? Could it refer only the rebels in a situation? Could it refer only government actors? ${ }^{163}$ Well, it probably could, but that does not mean the Judges and Prosecutor would be bound by such partial referrals, when Article 13(b) states that the referral is to cover the 'situation' in a country. Put another way, '[t]he Court... has no obligation whatsoever to comply with a 'referral' that does not comply with Art. 13(b). ${ }^{164}$ An analogy might here be made to the

159 See note 102 supra.

${ }^{160}$ A contrary argument might also be made that reserving exclusive jurisdiction to the troop-sending state inappropriately overrides applicable domestic jurisdiction that would otherwise exist. Author e-mails with C. Stahn.

${ }^{161}$ See Rome Statute, supra note 1, Art. 21.1(a).

162 See Rome Statute, supra note 1, Art. 13(b).

163 '[Another] way of seeing [the non-State Party carve-out of jurisdiction in Resolution 1593] is that it reflects the Security Council's wish to refer the situation in Darfur to the ICC except insofar as it regards personnel of non-state parties.' Cryer, supra note 46 , at 210 .

${ }^{164}$ As concluded in an International Peace Institute 'Meeting Brief':

The exclusion of certain groups from ICC prosecution [in Resolutions 1593 and 1970] is problematic.... At the time, this was considered necessary to secure political buy-in at the Security Council. However, the legality of exemptions has been challenged on the grounds that a Security Council referral can only activate the Rome Statute as a whole, not select parts thereof. It is therefore questionable whether these exemption clauses would withstand judicial scrutiny in the court itself, and they also expose the court to criticisms of selectivity. The wider negative implications for the ICC's credibility, impartiality, and independence suggest that future use of exemptions should be avoided.

Global Policy Forum, 'The Relationship Between the ICC and the Security Council: Challenges and Opportunities' (2012) International Peace Institute (www.global policy.org/international-justice/the-international-criminal-court/icc-in-the-securitycouncil-6-4/52118-the-relationship-between-the-icc-and-the-security-councilchallenges-and-opportunities.html). See also D. Kaye, 'The Council and The Court: Improving Security Council Support of the International Criminal Court' (2013) Univ. of California School of Law, at 6 (http://councilandcourt.org/files/2013/05/ The-Council-and-the-Court-FINAL.pdf) ('Some observers believe that, if such a situation were presented to a chamber of the Court, the judges may ignore the exemption [from investigation of citizens of non-state parties] and apply the Rome Statute, assuming jurisdiction and admissibility requirements are met.'); K.J. Heller, 
Uganda referral, when the Government of Uganda attempted to refer only the "situation concerning the Lord's Resistance Army" to the ICC, but the Office of the Prosecutor 'informed the Government of Uganda that it interpreted the referral to refer to all article 5 crimes of relevance to the situation. ${ }^{165}$ The OTP thus appropriately rejected a one-sided referral of less than the full 'situation,' because Article 14(1) of the Rome Statute permits a State Party to refer a 'situation' (not only one-side to the conflict). ${ }^{166}$ Similarly, there is at least a legal question whether a category of persons may be exempted from a referral in the way that Resolutions 1593 and 1970 purport to do. ${ }^{167}$ The directives that States Parties have given to the Prosecutor and Judges in Rome Statute Article 13(b) as to Security Council referral of a 'situation,' may well be less than the Security Council's own broad powers vis-à-vis U.N. Member States. Presumably, the Prosecutor and Judges also will interpret any referral in light of Rome

Footnote 164 continued supra note 105 ("the very first article of the Rome Statute provides that " $[\mathrm{t}] \mathrm{he}$ jurisdiction and functioning of the Court shall be governed by the provisions of this Statute."'); cf. Bergsmo, supra note 84, at 600 ("The drafting history of the ICC Statute makes it clear that the term "situations" that may be referred to the Prosecutor by a State Party of the Security Council was deliberately used to exclude the referral of individual cases for investigation.').

${ }^{165}$ See Draft OTP Policy Paper, supra note 23, at para. 35 (discussing the Uganda referral).

${ }^{166}$ See Rome Statute, supra note 1, Art. 14(1) ('A State party may refer to the Prosecutor a situation in which one or more crimes within the jurisdiction of the Court appear to have been committed....') (emphasis added).

${ }^{167}$ As Robert Cryer has argued: it seems not supportable that only certain persons can be referred (that there may be limitations 'ratione personae') and concluding '[i]f the Council can only refer situations... then it cannot limit the referral, even by excluding a small group.' Cryer, supra note 46, at 212. 
Statute Article 27 (no exemption from responsibility based on official capacity), as well as other provisions of the Rome Statute. ${ }^{168}$

Alternatively, rather than considering Resolutions 1593 and 1970 as 'partial' referrals, it is also possible to consider these resolutions as simultaneously Article 13(b) referrals of the situations in Darfur and Libya, and also Article 16 deferral as to certain nationals of nonStates Parties. ${ }^{169}$ (Indeed the preambles of Resolutions 1593 and 1970 'recall[]' Article 16 of the Rome Statute, suggesting this might have been intended.) But this interpretation also runs into difficulties. Three arguments suggest that the resolutions cannot be considered both referrals and deferrals: (1) Article 16 covers 'deferral of particular investigations or prosecutions' and not categories of individuals; (2) Article 16 is limited to a 12 month time-period, but there is no 'sunset clause' on the carve-out of jurisdiction as to nationals of nonStates Parties; and (3) questions could be asked about whether the 'immunity granted was demonstrably in the interests of international peace and security' (i.e., whether there was proper Chapter VII action that warranted the deferral part). ${ }^{170}$ It does not appear that non-ICC States Parties are implicated in any significant ICC crimes in Darfur

${ }^{168}$ Other relevant articles might be Article 12's jurisdictional regime and the purposes and principles of the Rome Statute, as articulated in the preamble, as well as other bodies of law - such as customary international law, jus cogens, and Genocide and Geneva Convention obligations, made relevant through Rome Statute Article 21.1(b).

Another argument is that these jurisdictional carve-outs are in effect amendments to the jurisdictional regime of the Rome Statute, and invalid because the Security Council has no power to amend the Rome Statute. See Cryer, supra note 46, at 213 ('the Security Council does not have the authority to alter the Rome Statute. The ICC is a separate international person to its members and is not a party to the UN Charter; therefore it is not bound by the trumping provisions contained in Article 103 of the Charter.'). See also n. 106 supra (arguing Resolution 1422 was an invalid attempt to amend the Rome Statute).

${ }^{169}$ See Cryer, supra note 46, at 209.

${ }^{170}$ Cryer, supra note 46, at 210-211. For example, one might ask:

[W]ould a [Security Council] decision attempting to coerce states to participate in a functional impunity of certain individuals who are reasonably accused of having committed or, for example abetted core crimes of genocide, other crimes against humanity, or war crimes (and later manifest aggression) actually serve peace, security, self-determination of peoples, and human rights?

Response to Kevin Jon Heller, supra note 105. Cryer notes that: 'The third way of seeing [the carve-out of jurisdiction as to non-ICC States Parties in Resolution 1593] is that it is an application of bilateral non-surrender agreements to the situation.' Cryer, supra note 46, at 210 (but concluding this is the least convincing reading). 
or Libya, so this issue will not be adjudicated for the time-being. ${ }^{171}$ Yet, it is far from clear that these exclusions from jurisdiction for the nationals of non-ICC States Parties are valid. ${ }^{172}$

It is a complicated issue whether to support a referral if the price of the referrals is to have provisions: (1) purporting to disallow the General Assembly from allocating U.N. funding to pay for the referral, and (2) purporting to exclude jurisdiction as to nationals of non-ICC States Parties from referral of the situation. Certainly in instances of extremely serious atrocity crimes such as those that occurred in Darfur - which this author has concluded constitute genocide $^{173}$ - this author supports the view that it is better to have the referral resolution, even if flawed. '[I]t is better to ensure that some international crimes are prosecuted than to risk no prosecutions by too strict an application of principle. ${ }^{174}$ Another view, however, would be possible, if, for example, peacekeepers from a non-ICC State Party had committed significant ICC crimes within the territory of a state that is the subject of a Security Council referral. Even absent that, it should not become standard practice to have these provisions in all Security Council referral resolutions, as they (1) create a significant financial predicament for the Court, (2) engender

${ }^{171}$ The carve-out from ICC jurisdiction for nationals of non-ICC States Parties that is part of the Kampala Review Conference amendment on the crime of aggression, see Rome Statute, supra note 1, Art. 15bis, para. 5, by contrast, is on a more secure foundation because it is an amendment to the Rome Statute, and the Judges and Prosecutor would be bound to adhere to it once activated. If there were perceived to be some inconsistency between the crime of aggression amendment and Article 27, that inconsistency was presumably waived by States Parties in Kampala. For background on the Kampala amendment process, see J. Trahan, 'Negotiating the Amendment on the Crime of Aggression: Proceedings at the Kampala Review Conference on the International Criminal Court' (2011) 11 Int'l Crim. L. Rev. 49.

${ }^{172}$ As argued in the summary paper of an International Peace Institute roundtable discussion: 'It is... questionable whether these exemption clauses would withstand judicial scrutiny in the court itself, and they also expose the court to criticisms of selectivity.' Papenfuss, supra note 69, at 1, para. 2. While some have argued that the Darfur referral, due to the carve-out as to non-States Parties is 'illegal,' see Jiminez, supra note 2, at 92, this author suggests that both the Darfur and Libya referrals are valid, but questions the efficacy of the carve-outs vis-à-vis the nationals of non-ICC States Parties. In other words, to the extent the Court finds particular language in Resolutions 1593 or 1970 problematic, it might be possible to construe that language as severable from the rest of the referral resolution. Author e-mails with C. Stahn.

${ }^{173}$ See J. Trahan, 'Why the Killing in Darfur is Genocide' (2008) 31 Fordham Int'l L. J. 990.

${ }^{174}$ Cryer, supra note 46, at 218. 
cynicism in terms of the unequal application of the rule of law vis-àvis the nationals of non-ICC States Parties, and (3) may be legally invalid.

\subsection{The Security Council Should Impose Cooperation Obligations on All U.N. Members States vis-à-vis Referred Situations}

The two Security Council referral resolutions to date also contain only cooperation obligations vis-à-vis the states subject to referral. ${ }^{175}$ Thus, for example, in the Libya referral, the Security Council '[d]ecides that the Libyan authorities shall cooperate fully with and provide any necessary assistance to the Court and the Prosecutor pursuant to this resolution.... ${ }^{176}$ The Darfur referral contains similar language obligating 'the Government of Sudan and all other parties to the conflict in Darfur' to cooperate with the Court and Prosecutor. ${ }^{177}$

It appears problematic to only have the countries subject to referral bear cooperation obligations. It is a matter of serious concern that all the ICC warrants against Sudanese government officials (as well as one Janjaweed leader) remain unexecuted. ${ }^{178}$ While Rome Statute States Parties owe cooperation obligations to the ICC (including vis-à-vis referred situations), ${ }^{179}$ non-ICC States Parties owe no such cooperation obligations. Thus, pressure has been put to bear on ICC States Parties not to, for example, permit Sudanese President Bashir to travel to their territories (or to arrest him if he does); this has seriously curtailed President Bashir's travel. ${ }^{180}$ Yet, President

${ }^{175}$ Resolution 1593, supra note 4, para. 2; Resolution 1970, supra note 5, para. 5.

${ }^{176}$ Resolution 1970, supra note 5, para. 5.

${ }^{177}$ Resolution 1593, supra note 4, para. 2.

178 These are the warrants in: The Prosecutor v. Ahmad Muhammad Harun ('Ahmad Harun') and Ali Muhammad Ali Abd-Al-Rahman ('Ali Kushayb'), ICC02/05-01/07; The Prosecutor v. Abdel Raheem Muhammad Hussein, ICC-02/05-01/12; and The Prosecutor v. Omar Hassan Ahmad Al Bashir, ICC-02/05-01/09. The ICC's voluntary summonses to appear against rebel commanders, by contrast, have resulted in the accused appearing before the ICC. Summons to appear, The Prosecutor v. Bahar Idriss Abu Garda, ICC-02/05-02/09; Summons to appear, The Prosecutor v. Abdallah Banda Abakaer Nourain and Saleh Mohammed Jerbo Jamus, ICC-02/05-03/09.

${ }^{179}$ Rome Statute, supra note 1, art. 86 ('States Parties shall, in accordance with the provisions of this Statute, cooperate fully with the Court in its investigation and prosecution of crimes within the jurisdiction of the Court.'). 
Bashir remains free to travel to the territories of non-ICC States Parties, because they do not owe any cooperation obligations to the Court and the Security Council's referral resolution only imposes cooperation obligations upon Sudan. ${ }^{181}$ A similar quandary was faced when Abdullah Al-Senussi, against whom an ICC warrant had been issued for crimes committed in Libya, was found in Mauritania; ${ }^{182}$ Mauritania - a non-ICC State Party - owed no obligation to turn him over to the ICC, and the referral resolution only imposed duties upon Libya.

Thus, in future U.N. Security Council referral resolutions, the Security Council should include text to the effect that it: 'Decides that all U.N. Member States shall cooperate fully with and provide any necessary assistance to the Court and the Prosecutor pursuant to this resolution.' The Security Council could also provide 'specific steps that a target state should take [as to cooperation], rather than simply obliging the state to "cooperate fully" with the Court." ${ }^{183}$ An obligation to cooperate imposed upon all U.N. Member States would help facilitate both execution of arrest warrants, as well as cooperation on other matters. ${ }^{184}$ Conditionality has also been suggested -

${ }^{180}$ Oral Statements of Richard Dicker, Director, International Justice Program, Human Rights Watch, made at the UN, 22 February 2013. Notes on file with the Author.

${ }^{181}$ States that are parties to the Genocide Convention arguably also owe some obligation to act pursuant to the extradite or prosecute obligations in that convention. See 1948 Convention on the Prevention and Punishment of the Crime of Genocide, 78 U.N.T.S. 277, Arts. 1 \& 4 (obligation to punish); Art. 7 (obligation to extradite).

182 'Mauritania deports Libya spy chief Abdullah al-Senussi', BBC News Africa, 5 September 2012 (http://www.bbc.co.uk/news/world-africa-19487228).

${ }^{183}$ Chatham House, supra note 33, at 18. The Security Council resolutions establishing the International Criminal Tribunal for the Former Yugoslavia and the International Criminal Tribunal for Rwanda also only contained wording obligating states to 'cooperate fully' with the respective tribunals. See U.N. Doc. S/RES/827 (1993), at para. 4; U.N. Doc. S/RES/955 (1994), at para. 2. 
that there be clear incentives linked to ICC cooperation. ${ }^{185}$ Because the Security Council's powers extend to all U.N. Member States, ${ }^{186}$ it clearly has the power to mandate cooperation with the ICC by all U.N. Member States as to referred situations, ${ }^{187}$ and could also play a role in supporting the ICC as to non-referred situations with which it is seized. ${ }^{188}$

${ }^{184}$ As discussion at an IPI roundtable concluded:

Future referrals would benefit from a provision making cooperation by all states mandatory. The Security Council has not lent sufficient support to the situations it has referred to the ICC. In order to make referrals effective, the council should follow up on referral decisions to enforce cooperation - for example, by imposing targeted sanctions (travel bans or asset freezes that could then serve to pay defendants' legal counsel or reparations to victims). States parties have adopted policies to address noncooperation among members of the Assembly of States Parties, yet they too can do more to support the court directly and indirectly by pressuring the Security Council to take action.

Papenfuss, supra note 69, at 2, para. 4. See also B. Ugarte, 'Enhancing Security Council Cooperation with the International Criminal Court', paper on file with the author (discussing the need to put ICC indictees on Security Council sanctions lists).

${ }^{185}$ See Chatham House, supra note 33, at 13 ('Taking inspiration from the EU's policy of conditionality when engaging with would-be EU member states, one possible strategy to encourage cooperation with the ICC could be the introduction of bilateral and multilateral incentives for cooperation.').

${ }^{186}$ U.N. Charter, supra note 30, Art. 25.

${ }^{187}$ The U.S. had a statutory ban on cooperation with the ICC. See ASPA, supra note 154, at $\S 2004$. That ban, however, has since been waived by the 'Dodd Amendment,' which states: 'Nothing in this title shall prohibit the United States from rendering assistance to international efforts to bring to justice Saddam Hussein, Slobodan Milosevic, Osama bin Laden, other members of Al Qaeda, leaders of Islamic Jihad, and other foreign nationals accused of genocide, war crimes or crimes against humanity.' Amendment No. 3787 to Amendment No. 3597 (www. amicc.org/docs/Dodd2nddeg.pdf) (emphasis added).

${ }^{188}$ As concluded in a Chatham House report:

In such scenarios [where the Security Council is seized of the matter], the Council could directly or indirectly provide support and cooperation to the Court when it has initiated investigations or issued arrest warrants in situations within its treaty-based jurisdiction.... This cooperation could take on many forms, some of which would not require the invocation of Chapter VII. Whether it be the simple provision of political and diplomatic support, both in public and privately, to the Court, or whether it be the coordination of its sanctions regime to support the Court's activities, or the strengthening of peacekeeping mandates to ensure that peacekeeping operations cooperate effectively with the Court's investigations, the Security Council could do a lot more to provide material support to the Court.

Chatham House, supra note 33, at 10. 


\section{THE NEED FOR SECURITY COUNCIL FOLLOW-UP TO ITS REFERRALS}

A final concern as to the text of the referral resolution, as well as the Security Council's role regarding the referral, is whether it is sufficient for the Security Council to make a referral, or whether it ought to have some continuing obligation as to the referral. One frequently heard complaint with the two existing referrals is that while the ICC Prosecutor is required twice yearly to brief the Security Council as to progress on the referred situations, ${ }^{189}$ the Security Council does not seem to regard itself as having any on-going commitment to ensure that investigations and/or prosecutions actually proceed, ${ }^{190}$ or, has only recently come to consider itself to have follow-up obligations. ${ }^{191}$ While, as noted above, both referral resolutions contain language that the states subject to referral bear cooperation obligations, ${ }^{192}$ and States Parties to the ICC are statutorily obligated to cooperate under the Rome Statute, ${ }^{193}$ these obligations do not necessarily translate into successful investigations and/or prosecutions. For example, as noted above, due to the fact that none of the arrest warrants for crimes committed in Darfur have been executed, most of

${ }^{189}$ Resolution 1593, supra note 4, para. 8; Resolution 1970, supra note 5, para. 7. 190 'It was observed that one of the greatest dangers to the effectiveness of the Court is the failure of the Council to provide follow up support to the ICC once it has referred to it a situation.' Chatham House, supra note 33, at 9.

${ }^{191}$ On 12 February 2013, the Council adopted a Presidential Statement (PRST) on Protection of Civilians in Armed Conflict, which, in para. 9, highlights the role of the ICC and specifically mentions the importance of effective follow up:

The Security Council notes that the fight against impunity and accountability for the most serious crimes of international concern has been strengthened through the work on and prosecution of these crimes in the International Criminal Court, in accordance with the Rome Statute, in ad hoc and 'mixed' tribunals as well as specialized chambers in national tribunals. In this regard, the Security Council reiterates its previous call on the importance of State cooperation with these courts and tribunals in accordance with the states' respective obligations, and expresses its commitment to an effective follow up of Council decisions in this regard.

Security Council PRST 2012/2, para. 9 (emphasis added).

192 Resolution 1593, supra note 4, para. 2; Resolution 1970, supra note 5, para. 5. ${ }^{193}$ Rome Statute, supra note 1, Art. 86. 
the ICC's Darfur cases have ground to a halt. ${ }^{194}$ While 'the Court has notified the Security Council of instances of non-cooperation by states in their failure to give effect to ICC arrest warrants arising out of the referral of the situation in Darfur,' 'the Council has failed to take any action pursuant to those notifications. 195

The need for the Security Council to bear follow-up obligations to help ensure that its referrals actually succeed, was recently persuasively addressed by the ICC's Pre-Trial Chamber II:

[U]nlike domestic courts, the ICC has no direct enforcement mechanism in the sense that it lacks a police force. As such, the ICC relies mainly on the States' cooperation, without which it cannot fulfil its mandate. When the Security Council, acting under Chapter VII of the UN Charter, refers a situation to the Court as constituting a threat to international peace and security, it is expected that the Council would respond by way of taking such measures which are considered appropriate, if there is an apparent failure on the part of the relevant State Party to the Statute to cooperate in fulfilling the Court's mandate entrusted to it by the Council. Otherwise, if there is no follow up action on the part of the Security Council, any referral by the Council to the ICC under Chapter VII would never achieve its ultimate goal, namely, to put an end to impunity. Accordingly, any such referral would become futile. ${ }^{196}$

It is noteworthy that when the Security Council imposes sanctions, it frequently creates a 'sanctions committee' to monitor implementation of sanctions; one idea that warrants consideration is whether there should be some kind of 'Security Council working group for ICC referrals' (similar to the Security Council's working group on Tribunals) or other forum to remain fully up-to-date on the ICC's

\footnotetext{
${ }^{194}$ See n. 74 above (Bashir warrants).

195 Chatham House, supra note 33, at 9. The Court has made findings of noncompliance against Rome Statute State Parties that do not adhere to their obligations, such as Chad's failure to arrest Sudanese President Bashir - against whom there are two pending ICC arrest warrants - upon his visit to Chad. The ICC notified both the Security Council and ICC Assembly of States Parties of the non-compliance. See The Prosecutor v. Omar Hassan Ahmad Al Bashir, Decision on the NonCompliance of the Republic of Chad with the Cooperation Requests Issued by the Court Regarding the Arrest and Surrender of Omar Hassan Ahmad Al-Bashir, ICC02/05-01/09, 26 March 2013 (Pre-trial Chamber II) (hereinafter, 'Decision on the Non-Compliance of Chad').

196 Decision on the Non-Compliance of Chad, supra note 195, at para. 22. See also, e.g., U.N. Doc. S/2012/731 (2012), 'Letter dated 1 October 2012 from the Permanent Representative of Guatemala to the United Nations addressed to the Secretary General,' para. 10 ('Follow-up by the Council on its own referrals to the Court is important for the credibility of the Council and for the legitimacy of international criminal justice.').
} 
work on referred situations and assist the ICC should requests be made. ${ }^{197}$ The Council also might consider the harmonization of sanctions mechanisms, such as asset freezes and travel bans, with ICC indictments. ${ }^{198}$ To date there has been no automaticity of asset freezes or travel bans when the ICC has issued arrest warrants; rather, designation of individuals subject to asset freezes and travel bans remains subject to voting by relevant Security Council committees. ${ }^{199}$ An additional possibility is that, to the extent the Security Council is unresponsive to reports of non-cooperation, the ICC might consider engaging the U.N. General Assembly, ${ }^{200}$ for example, when the ICC President provides an annual report to the General Assembly. As suggested above, including text in the referral resolution that mandates all U.N. Member States cooperate with the referral would also facilitate follow-up.

If too many of the Security Council's referrals do not result in successful ICC prosecutions, this ultimately undermines both the referral process and, ultimately, the Security Council's credibility and any potential threat of deterrence that referral could carry. Thus, the Security Council should have an interest in ensuring the success of its own referrals lest this mechanism become a hollow gesture.

${ }^{197}$ A recent Chatham House committee report explains:

Drawing upon the practice of establishing Sanctions Committees to monitor the implementation, enforcement and consequences of the sanctions regimes imposed under Chapter VII, it was suggested that similar subsidiary bodies could be established to focus upon referrals to the ICC. This, it was suggested, might stimulate better follow-up by the Council.

Chatham House, supra note 33, at 10. See also Papenfuss, supra note 69, at 2, para. 7 ('Dedicated fora should also address issues concerning situations referred to the ICC. The Security Council's informal working group on tribunals could be expanded to deal with ICC issues, or a separate mechanism could be created.'); ibid., at 2, para. 6 ('For example, [the Security Council] could regularly hold open debates on peace, justice, and the ICC. It should also develop a coherent accountability agenda and refrain from endorsing amnesties and using the veto when Rome Statute crimes appear to have been committed.').

198 See Chatham House, supra note 33, 9 ('there is a need for the [harmonization] of sanctions imposed by the Council against individuals who are also sought by the Court.').

${ }^{199}$ See, e.g., Resolution 1970, supra note 5, paras. 15-22 (creating travel bans and asset freezes for individuals implicated in 'serious human rights abuses' to be designated by a sanctions committee of the Security Council).

${ }^{200}$ Author e-mails with C. Stahn. 


\section{CONCLUSION}

The Security Council's referral and deferral powers under the ICC's Rome Statute are extremely significant because a political body has a role in determining who stands in the docket of a judicial institution. The ICC's institutional autonomy is preserved in the event of a referral, because the Prosecutor only proceeds if she or he independently believes that there is a reasonable basis to proceed with the investigation. In the event of a deferral, however, it is unclear whether the Prosecutor or Judges would have any power to override a properly made deferral but arguably should only adhere to a proper deferral request that satisfies the standards of the Rome Statute. ${ }^{201}$ It is key to understand the legal parameters of when referrals and deferrals are permissible and should be granted, and identify best practice recommendation, if any. A summary of the conclusions and recommendations made in this article is contained in Appendix A hereto.

\section{OPEN ACCESS}

This article is distributed under the terms of the Creative Commons Attribution License which permits any use, distribution, and reproduction in any medium, provided the original author(s) and the source are credited.

\section{APPENDIX A: SUMMARY OF CONCLUSIONS}

\subsection{Referrals}

As to the Security Council's power to refer situations, the following observations may be made.

\section{Minimum Requirements for Security Council Action}

- Chapter VII of the U.N. Charter requires only a threat to the peace, breach of the peace, or act of aggression' before the Security Council may act.

201 ' $[\mathrm{T}]$ he Court is the final arbiter over the interpretation of the Statute. One may therefore infer that it is vested with the authority to refuse to implement a Council request that exceeds the limits of Article 16 of the Statute.' Stahn, supra note 29, at 102. 
- Rome Statute Article 13(b) reiterates that a referral be made pursuant to Chapter VII.

- Rome Statute Article 13(b) additionally requires that one or more ICC crime 'appears to have been committed.'

- Given the magnitude of most ICC crimes, the requirement of one or more ICC crime is not that low of a threshold, and most likely will also meet the requirement of a 'threat to the peace, breach of the peace, or act of aggression.'

\section{Whether the Security Council is Ever Obligated to Act}

- The Security Council is charged with maintaining international peace and security under the U.N. Charter and a referral might be one possible, but not necessarily a sufficient, step towards doing so.

- The 'responsibility to protect' doctrine suggests that the Security Council has an increasingly solidifying legal obligation to act in the face of large scale atrocity crimes, with referral again constituting one possible, but not necessarily a sufficient, step.

Considerations as to Timing of a Referral and Deterrence

- While the minimum requirements for action suggest that the Security Council may act fairly early on in referring a situation, if it waits too late in the day, any deterrent value of the referral will be lost or significantly diminished.

\section{Considerations as to Use of the Veto}

- Where large-scale atrocity crimes such as genocide, war crimes, and crimes against humanity are occurring, the Permanent Members of the Security Council should refrain from use of their veto power, including, but not limited to, referrals.

\section{Considerations as to Institutional Consistency}

- As a policy matter, the Security Council should be concerned about consistency in making referrals for the sake of its own institutional credibility, and to show itself as a responsive institution when faced with mass crimes if they rise to the level of a threat to international peace and security.

- The Security Council should act as objectively and consistently as possible in making referrals.

- Consistency in referrals would enhance the deterrent value of the court. 
Observations as to Referrals to Date

- Under the above criteria, the Darfur and Libya referrals met the criteria for referral. The criteria would also be met for referring the situation in Syria. The delay in making a Syria referral harms any deterrent value that might be derived from referral. The making of the Libya referral (fairly early on in terms of commission of crimes) and delay in making a Syria referral and lack of other referrals suggest a lack of institutional consistency on the part of the Security Council. The lack of a Syria referral and other referrals (or other robust action to prevent ongoing crimes) also suggests an abdication by the Security Council of its responsibility to protect against large-scale atrocity crimes.

\subsection{Deferrals}

As to the Security Council's power to defer situations, the following observations may be made.

\section{Requirements for Deferral}

- The Security Council's power to make a deferral derives from Chapter VII of the U.N. Charter. It must be in response to a 'threat to the peace, breach of the peace or act of aggression.'

- Rome Statute Article 16 reiterates that the Security Council may only act pursuant to Chapter VII.

- Rome Statute Article 16 also provides that no ICC investigation or prosecution' may be commenced or proceeded with in the event of deferral. This may impose the requirement that the Security Council may only defer a particular 'investigation or prosecution.'

- Rome Statute Article 27 provides that there may be no exemption from ICC responsibility for certain persons, including 'government official[s].'

- Other provisions of the Rome Statute, the U.N. Charter, jus cogens, customary international law, and treaty obligations may also be relevant to assessing the validity of a deferral.

\section{Considerations as to Good Policy}

- While the Security Council has the power to act in the face of a 'threat to the peace,' it is good policy not to allow a person or state to benefit from deferral if the person or state created the 'threat to the peace.' 


\section{Observations as to Deferrals to Date}

- Under the above criteria, in issuing Resolutions 1422 and 1487, the Security Council may or may not have acted in response to a threat to the peace - a threatened withdrawal from peacekeeping operations. It is also questionable as a policy matter whether a state making the threat should benefit from such a deferral. It is unclear whether Rome Statute Article 16 only permits deferral of an actual 'investigation or prosecution' or whether it can be made proactively to prevent an investigation or prosecution from arising against a group of persons. Even if Resolutions 1422 and 1487 were properly made in terms of the Security Council's power, the Prosecutor and Judges are governed by the Rome Statute, and Article 27 excludes immunity for government officials. Additional legal considerations also suggest the questionable legal validity of Resolutions 1422 and 1487. At minimum, there is a tension between the Security Council's deferral resolutions and the Rome Statute, as well as other sources of law. Accordingly, there is a question whether Resolutions 1422 and 1487 were proper Article 16 deferrals.

\section{Observations as to Deferrals Requested}

- Under the above criteria, the warrants against Sudanese President Bashir and investigations and prosecutions against three Kenyan individuals did not cause any threat to the peace, breach of the peace, or act of aggression that would warrant Chapter VII action. While the situation in Kenya at various times has threatened or breached the peace, that resulted from underlying ethnic and political tensions, not the ICC's investigation. Even if President Bashir's expulsion of humanitarian workers did cause a 'threat to peace' at one point in time, that threat ended and the person threatening the peace should not be rewarded with deferral of his or her investigation or prosecution.

\subsection{Text of the Referral Resolution}

As to the text of the referral resolution:

\section{Funding}

- The Security Council should be silent as to funding of the referral, leaving it to the General Assembly to consider the issue of funding. Article 17.1 of the U.N. Charter provides that ' $[\mathrm{t}$ ]he General 
Assembly shall consider and approve the budget of the Organization.' A question exists whether the Security Council has the competence to instruct the General Assembly not to fund referrals.

\section{Non-states Parties}

- The Security Council should refrain from excluding nationals from non-State Parties from jurisdiction. Under Rome Statute Article 13(b), the Security Council may refer a 'situation' to the ICC. This language arguably disallows referral of less than a full situation. A question exists whether troops from non-ICC States Parties may properly be excluded from referral of the 'situation' as they have been (or purportedly have been) in Resolutions 1593 and 1970. Put another way, the Security Council likely has power to issue such exclusions (given its broad Chapter VII powers), but the Prosecutor and Judges take their instructions from the Rome Statute, which appears to exclude a partial referral. Rome Statute Article 27 (non-immunity as to officials) may also be relevant, as well as other Rome Statute provisions and other sources of law.

\section{Severability}

- Should the ICC find that any of the clauses in Resolutions 1593 and/or 1970 are invalid, it would be preferable for the Court to interpret those clauses as severable and not treat the entirety of the referrals as invalid.

\section{Cooperation}

- The referral resolution should contain an obligation that all U.N. Member States cooperate regarding the referred situation, not only the country at issue.

- It would be useful if the Security Council could provide specific steps that a target state should take as to cooperation, rather than simply obliging the state to cooperate fully with the Court.

- The Security Council could also support non-referred ICC situations where it is seized with them.

\subsection{Follow Up Mechanism for Referrals}

As to the need for follow-up to ensure successful investigations and prosecutions result from Security Council referrals:

- Consideration should be given to creating a follow-up mechanism after the Security Council makes a referral. One possible model is a 
'Security Council working group for ICC referrals,' similar to the Security Council working group on Tribunals.

- The Security Council should take consistent action in instances of non-cooperation

- The ICC should considering going to the U.N. General Assembly if the Security Council is insufficiently responsive to instances of noncooperation reported to it.

- The Security Council could harmonize the imposition of sanctions such as asset freezes and travel bans to automatically cover individuals subject to ICC indictment.

- Including language in the referral resolution imposing cooperation obligations on all U.N. Member States regarding the referred situation would also facilitate follow-up. 